\title{
PLEITOS DE LA VILLA DE ALBACETE A MEDIADOS DEL SIGLO XVI
}

\section{DISPUTES IN THE TOWN OF ALBACETE IN THE MID $16^{\mathrm{TH}}$ CENTURY}

\author{
Pedro Joaquín García Moratalla \\ Instituto de Estudios Albacetenses \\ Albacete, JCCM, España \\ garciamoratalla@gmail.com
}

Cómo citar este artículo: García Moratalla, P.J. (2020). Pleitos de la villa de Albacete a mediados del siglo XVI. Al-Basit (65), 203-255. http://doi.org/10.37927/al-basit.65_6

Recibido/Received: 01-09-2020

Aceptado/Accepted: 20-07-2020

RESUMEN: A mediados del siglo XVI, la villa de Albacete se hallaba inmersa en una serie de pleitos que ya venían de antaño, aunque alguno se originó entonces y otros se prolongarían más allá de ese momento. Los roces con las poblaciones vecinas de Chinchilla y La Gineta fueron constantes, por razón de términos e intromisión de unos y otros. La merma de las arcas concejiles estuvo motivada en gran parte por los desembolsos correspondientes a los enfrentamientos con este último lugar, seguido de los relativos al conflicto con las tierras de Jorquera y Alcalá, señorío del marqués de Villena y duque de Escalona. La larga duración de los litigios era la causa de los sobrecostes. El mantenimiento, en la Corte y en la Chancillería de Granada, de letrados, procuradores y solicitadores, así como el envío de peones y gestores locales con mensajes y
ABSTRACT: In the mid 16th Century, the town of Albacete was immersed in a series of disputes that already came from long ago, although some were originated then and others would last longer. The fights with the neighboring towns of Chinchilla and La Gineta were constant, due to terms and meddling from one to another. The decrease in the public treasure was mainly motivated by the expenditures to afford the confrontations, along with those related to the conflict with the lands of Jorquera and Alcalá, manor of the marquis of Villena and duke of Escalona. The long lasting of the fighting led to cost overruns. The payout, at the Court and the Chancery of Granada, of lawyers, attorneys and solicitors, as well as the dispatch of local laborers and managers with specific messages and orders, largely undermined the funds of the Albacete council. 
órdenes determinadas, minaron en gran parte los fondos del concejo albaceteño.

PALABRAS CLAVE: Pleitos, marqués de Villena, Chancillería de Granada, Corte de Valladolid, concejo Albacete, términos de Chinchilla y La Gineta, gastos y sobrecostes.
KEYWORDS: Disputes, marquis of Villena, Chancery of Granada, Court of Valladolid, council of Albacete, terms of Chinchilla and La Gineta, expenses and overruns.

\section{INTRODUCCIÓN}

Cualquier metodología utilizada en la investigación histórica debería tener el mismo fin, que sería el de conseguir un testimonio más veraz y aproximado del acontecimiento pretérito. La orientación que abordamos aquí, está basada fundamentalmente en el escudriñamiento de las fuentes originales, y completada, en la medida de lo posible, por aquellos estudios locales que ayuden a mejorarla y a darle más consistencia. Los nuevos contenidos inéditos que salen a la luz con este proceder quedan prestos a ser utilizados por otros investigadores $\mathrm{y}$, además, con las referencias de archivo señaladas y expuestas.

No vamos a inflar este artículo con disertaciones que podrían dar sensación de mayor erudición retórica, pero que en nada contribuirían a procurar una mayor información ni aclaración respecto al tema que se trata. No queremos construir edificios de ensueño, nos conformamos con extraer sus piedras de la cantera. Tampoco recurrimos a entresacar lo más jugoso, olvidando el resto del escrito primigenio como desechable, pues olvidaríamos la atmósfera en que están envueltos los acontecimientos de la época que tratamos.

Aunque los comentarios personales hacen más digerible y ameno el contenido de los hechos, el paso inmediato sería irremediablemente al debate y a la controversia. La línea entre interpretación y opinión es muy delgada. Para que cualquier reflexión sea históricamente válida debe estar avalada con suficiente evidencia por el acopio documental todavía inexplorado del momento que se estudia. El investigador debe dar respuestas en base a esos textos y a lo descubierto en ellos, tratando de extraer y exponer su contenido intrínseco. Cuando vamos pegados al escrito original, la metodología pueda resultar así llana, exenta de literatura y menos atractiva, y especialmente en el tema que tratamos. Basta observar cualquier escrito o resolución relativa a procesos para admitir que la amenidad expositiva brilla por su ausencia, debido 
a los continuos vaivenes de un mismo conflicto en su largo recorrido. Pero sí se garantiza mayor fiabilidad a la hora de mostrar a sucesivos historiadores los hechos y acontecimientos que se exponen. Quedaría así todo lo transcrito como garante de lo que se concluye sobre el papel. Por ello, iremos siempre arrimados al documento, demostrando preocupación e insistencia por revelar su veracidad con las citas pertinentes, aunque a veces resulte tedioso para los poco o nada versados en paleografía. Que sea el lector quien extraiga su razonamiento, dejando el condimento a su libre albedrío.

En la redacción se incluyen muchos textos originales. Tratamos de evitar así el peligro del casi seguro error que conllevaría toda especulación sobre hechos tan lejanos en el tiempo y faltos, en la mayoría de los casos, de otros manuscritos transversales que aseveren y confirmen categóricamente lo descrito. Por eso hemos utilizado fuentes y bibliografía exclusivamente local. Pues pensamos que este enfoque, libre de cualquier encorsetamiento académico, tiene la ventaja de afrontar la historia del conjunto de nuestros pueblos conociendo primero la de cada uno de ellos, para después generalizar en base a esos estudios particulares.

El tiempo en el que emerge el contenido que aquí se trata coincide con el inicio del reinado de Felipe II (1556-1598). El concejo albaceteño estaba formado básicamente por varios regidores, dos alcaldes ordinarios, un alguacil mayor y dos alcaldes de hermandad (uno del estado de hidalgos). Los primeros participaban con voz y voto en todos los asuntos municipales y fueron en un principio elegibles, en un número de seis. Desde mediados del siglo XVI la monarquía convirtió los regimientos en perpetuos, con la venta del cargo, obteniendo así beneficios económicos para la Corona, a la vez que se pretendía que quienes lo ocupasen fueren personas de calidad para administrar la población. En Albacete aparecen ocho regidores perpetuos a partir de 1543. Su número iría aumentando con el tiempo. En 1555 había doce y en 1561 llegaban a dieciocho (García Moratalla, 2020, p. 15).

Este gobierno municipal se encargaría de dirigir los destinos de la villa y resolver todos los asuntos locales motivo de controversia. Éstos eran tratados en primera instancia por la justicia local, correspondiente en este caso a los dos alcaldes ordinarios. Cabía el recurso ante el gobernador del Marquesado de Villena, residente en San Clemente, tanto de cuestiones vecinales como de los enfrentamientos habidos entre dos o más poblaciones. En este último caso, a tenor de las escasas referencias, es evidente que la parte disconforme con el veredicto apelaría casi siempre a instancias superiores.

Dejando aparte los procesos tocantes a la constante intromisión de gobernadores o corregidores en la primera instancia del lugar, de- 
dicaremos preferentemente este trabajo a los pleitos que la villa de Albacete mantuvo con otros pueblos.

Numerosos fueron los litigios; algunos de ellos se venían arrastrando desde muchos años atrás, especialmente con el duque de Escalona y sus villas de Jorquera y Alcalá (relativo a la comunidad de términos) y "con otras onze villas deste marquesado". Con la ciudad de Chinchilla sobre los montes; y con la villa de La Gineta, "que fue aldea desta villa, sobre el término e juridiçión. E que ordinariamente tiene veinte o treinta pleitos en Corte i en Granada y ante la justiçia maior"1.

\section{LA GESTIÓN DE LOS PLEITOS}

La estancia de apoderados del concejo de Albacete en San Clemente, Valladolid o Granada era determinante, no sólo para la gestión de las causas que allí se trataban, sino para los asuntos más diversos. El mantenimiento de esa permanencia y salarios, era a costa del ayuntamiento, ocasionando a veces las protestas de los oficiales por el gasto excesivo, o inadecuado, de quienes trataban de solucionar esos menesteres. Se mantenía pues a letrados (abogados) que libraban los pleitos y a procuradores y solicitadores que se ocupaban de los trámites burocráticos al respecto.

Los procuradores eran elegidos para iniciar los trámites. Distinguimos al procurador del concejo, nombrado para ocuparse de todo tipo casos, tanto los que estaban en litigio como los que no. Era un gestor itinerante. Tenían salario anual pagado por tercios del año, de cuatro en cuatro meses. En Albacete aparece Miguel Sánchez en las cuentas de propios de 1555-1556, con seis ducados de salario anual ${ }^{2}$. Todavía cobró honorarios en las cuentas siguientes ${ }^{3}$. En las de 15571558 ocupaba el puesto Ginés Gómez y, en las de 1558-1559, volvería a serlo Miguel Sánchez ${ }^{4}$. En 1559-1560 y 1560-1561 aparece Garci Hernández de Córdoba como tal, todavía con el mismo estipendio 5 .

El consistorio elegía a otros procuradores de entre personas que ya estaban en la Corte o en Granada y que atendían además los casos de otras poblaciones al mismo tiempo. Se intentaba mantener en el cargo a la misma persona durante el mayor tiempo posible, dado que podían entender y llevar con mejor continuidad los pleitos duraderos.

${ }^{1}$ A.H.P. de Albacete. Sec. Municipios. Caja 4507. Actas capitulares 1552-1562. Sesión del 16-VII-1558. Fols. 276rํ-276vo .

${ }^{2}$ Ibídem. Caja 4578. Libro 228. Cuentas de propios 1552-1564. Cuenta del 29-IX1555 a 29-IX-1556.

${ }^{3}$ Ibídem. Cuenta del 29-IX-1556 a 29-IX-1557.

${ }^{4}$ Ibídem. Cuenta del 29-IX-1558 a 29-IX-1559.

${ }^{5}$ Ibídem. Cuenta del 29-IX-1559 a 29-IX-1560. 
Circunstancia ésta que fue habitual en épocas posteriores (Córcoles, 2008, p. 154). Tenían carta de poder del concejo para representarlo legalmente. En los intervalos temporales en que no había litigios, casi siempre seguían manteniendo su salario.

Los solicitadores eran nombrados, normalmente, de entre vecinos de la villa que tenían una instrucción mínima, como escribano, regidor, bachiller, etc. Uno para asuntos directos, como el bachiller Díaz, y otros que se encargaban de los trámites legales en la Chancillería de Granada o en la Corte de Valladolid, durante un tiempo determinado. Se les revocaba el poder una vez finalizada su misión, bien porque no hubiese asuntos que gestionar, bien porque el concejo no dispusiese de dinero para mantenerlo en su puesto o por disconformidad con su tarea.

No obstante, siempre y cuando el consistorio lo determinase, podía darse el caso de que el procurador hiciese también las funciones de solicitador, aún a pesar de mantener a otro exclusivo para ese puesto. Es, por ejemplo, el caso de Tristán Calvete, solicitador y procurador en Corte, que llevó los asuntos de la villa hasta 1560, con la habitual paga anual de seis ducados.

También el ayuntamiento tenía abogados para sus trámites directos, como el bachiller Munera, con idéntica remuneración que el solicitador ${ }^{6}$. Otros los tenía en Granada o en Valladolid, como veremos.

\subsection{En la Chancillería de Granada}

El concejo albacetense, como todos los ubicados al sur del Tajo, debía solventar sus litigios generales en la Chancillería de Granada. Allí mantenía, hacia 1556, a los letrados Tello Fernández y Juan Fernández. Éste último había muerto recientemente, nombrando en su lugar al licenciado Jara. Los dos recibían la acostumbrada retribución de seis ducados cada uno ${ }^{7}$.

El cargo de procurador lo ocupó Martín de Carvajal, por lo menos hasta 1560, según se desprende de algunas referencias en las cuentas de propios tocantes a su gestión ${ }^{8}$. En la sesión del ayuntamiento del 7 de julio de 1561 aparece otro, llamado Francisco Aguilera que entendería en el pleito con Jorquera' 9

\footnotetext{
${ }^{6}$ A.H.P. de Albacete. Secc. Municipios. Caja 4578. Libro 228. Cuentas de propios 1552-1564. Cuenta del 29-IX-1560 a 29-IX-1561.

7 Ibídem. Caja 4507. Actas capitulares 1552-1562. Sesión del 10-II-1556. Fol. $169 \mathrm{v}$.

${ }^{8}$ Ibídem. Caja 4578. Libro 228. Cuentas de propios 1552-1564. Cuenta del 29-IX1557 a 29-IX-1558 y cuenta del 29-IX-1559 a 29-IX-1560.

${ }^{9}$ Ibídem. Caja 4507. Actas capitulares 1552-1562. Sesión del 7-VII-1561. Fol. 377roo .
} 


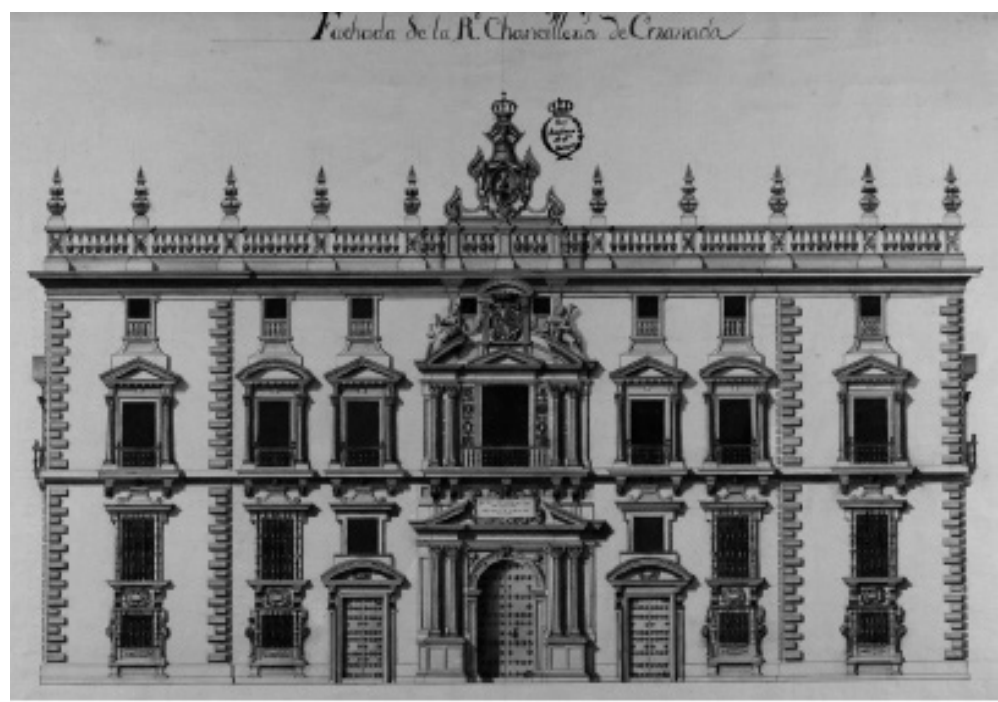

Real Chancillería de Granada (1531-1587). Dibujo anónimo del siglo XVIII ${ }^{10}$.

Hasta finales 1554, estuvo ocupando el puesto de solicitador del concejo Francisco de Cantos, después alcalde ordinario electo en octubre de 1555. En las cuentas de propios consta que un peón le llevó a Granada una carta y otros despachos, así como cuarenta ducados para su gestión ${ }^{11}$. Dos años después sus cabezaleros testamentarios recibirían la liquidación de los honorarios que el susodicho había ganado "soliçitando los pleitos queste conçejo trata en la dicha çiudad de Granada, sobre hidalguías e aprovechamiento de términos e otros pleitos ${ }^{\prime 2}$.

$\mathrm{Al}$ quedar vacante el puesto $\mathrm{y}$, por requerimiento del procurador del concejo Martín Carvajal, se nombró a Alonso Hernández, que "a estado otras vezes en los dichos negoçios y los a fecho mui bien y dado buena quenta dellos, ... e le asinaron siete rreales de salario cada vn día"13. Como era también recaudador real, circunstancia en que estaba ocupado en ese momento, alega para que se nombre otro solicitador en su lugar, eligiéndose como tal a su hijo Pedro Cebrián, escribano como él, "al qual mandaron se parta luego"14.

El recién nombrado Cebrián, aparece ejerciendo su oficio desde ju-

\footnotetext{
${ }^{10}$ Academia de Bellas Artes San Fernando. Museo, no A-0909.

${ }^{11}$ A.H.P. de Albacete. Secc. Municipios. Caja 4578. Libro 228. Cuentas de propios 1552-1564. Cuenta del 29-IX-1554 a 29-IX-1555

${ }^{12}$ Ibídem. Cuenta del 29-IX-1556 a 29-IX-1557.

${ }^{13}$ A.H.P. de Albacete. Sec. Municipios. Caja 4507. Actas capitulares 1552-1562. Sesión del 2-V-1555. Fols. 132vo-133vo.

${ }^{14}$ Ibídem. Sesión del 18-VI-1555. Fol. 137vo․
} 
nio de 1555 hasta 1557, en que se le revocó definitivamente el poder para solicitar en nombre de la villa. En ese tiempo, se le requirió en varias ocasiones que abandonase Granada y retornase a Albacete, como veremos en el pleito de los Alfaros. La primera de ellas fue a los tres meses y medio de su nombramiento. A primeros de noviembre de 1555 el ayuntamiento acordó que, puesto que la villa no tenía propios, se le escribiese para que, una vez visto el pleito de la taja (tributo sobre el ganado), se viniese; "y si no se obiere vysto quinze días antes de Navydad, se venga e no fíe más costas desta villa"15. El 14 de diciembre se ordena al mayordomo del concejo que "venda çinquenta fanegas de trigo para que se le enbíen a Pedro Çebrián, soliçitador en Granada, para las costas que debe, y se venga luego y no esté a costa del conçejo", al tiempo que también se requería el regreso del bachiller Alarcón, que igualmente estaba como tal solicitador en la Corte, "y anbos vengan, para más tarde, Navidad primera que viene y no gasten costas desta villa"16.

No obstante, el alcalde ordinario, y bachiller, Francisco de Cantos no era partidario de que Cebrián cesase en su puesto en Granada, dando motivos para su permanencia, por estar los pleitos aún pendientes de solución:

[...] porque, acabados (los procesos), esta villa quedará en paz con los comarcanos con quien trata pleitos, e así que conviene mucho questé e les dé fin. E tiene notiçia que le an mandado en este ayuntamiento que se venga. Por tanto quél, como açesor, aconseja, y como ofiçial dél, bota que se esté i dé fin. Y rrequiere a los dichos sennores le provean de lo neçesario, pues que con poca cosa estará proveído hasta que se acabe; donde no, que sea a culpa i cargo de los sennores del conçejo las demás dilaçiones y gastos que oviere en los dichos negoçios y perjuzios ${ }^{17}$.

Como veremos en la causa que se trataba sobre la hidalguía de los Alfaros, en marzo, abril, agosto y noviembre de 1556, el consistorio le ordenaría de nuevo que retornase a Albacete. Esta vez sí, pero en diciembre, ya está dando cuenta de su gestión en la villa manchega. Además, en lo referente a otros asuntos que tramitaba, señaló que el caso del duque de Escalona no lo había seguido. Sobre el horno con los Villena, que había presentado las escrituras. Sobre el asunto de Campillo, que había manda-

\footnotetext{
${ }^{15}$ A.H.P. de Albacete. Sec. Municipios. Caja 4507. Actas capitulares 1552-1562. Sesión del 3-X-1555. Fols. 162vo-163vo .

${ }^{16}$ Ibídem. Sesión del 14-XII-1555. Fol. 165o․

${ }^{17}$ Ibídem. Sesión del 31-XII-1555. Fols. 166vo-167ro․
} 
do la ejecutoria. Y también, entre otras cosas, que se había presentado en el pleito de Chinchilla ${ }^{18}$.

Después, como veremos, retornaría otra vez a Granada ${ }^{19} \mathrm{y}$, a mediados de septiembre de 1557 el concejo determina el regreso definitivo de este solicitador, incluso se dan muestras de satisfacción por su buena gestión. El motivo de pedir su cese estaba en la falta de dinero en las arcas municipales. Se acordó enviarle setecientos reales para finiquitar pagos.

Y que déstos pague lo que se deviere en Granada a honrradas e otras personas que se devieren derechos. Y traiga los traslados de las sentençias avtorizadas, porque después se traygan la esecutoria a esta villa. E porque a los dichos sennores les paresçe que los pleitos questa villa tiene en la çibdad de Granada no ai para questé soliçitador en ella, espeçialmente estando tan gastado este conçejo, mandavan e mandaron que venga el dicho Pedro Çebrián, e para hello le rrevocan e rrevocaron el poder questa villa le tiene dado y otorga rraçón de estado en que están los demás pleitos ${ }^{20}$.

En compensación a su buena labor el concejo determinó que "se le dé de albriçias seis mill marauedís pora ayuda a vn vestido", al mismo tiempo que también se gratificaba al letrado Tello Hernández con "sesenta rreales, demás de su salario". Y se sigue insistiendo a Cebrián que, antes de venirse, liquide cuentas con todas las personas a quien se debiere dinero; "donde no, que a su costa se bolverán a pagar"21.

Como en ese momento los letrados no entendían en pleitos, se acuerda que no haya nada más que uno, quitando al licenciado Jara, que lo era también de Ves, con quien Albacete pleiteaba, y dejando sólo al expresado Tello $^{22}$. Cinco días después se acordó tomar dinero prestado de cuatro vecinos, Alonso Galiana, Martín Sánchez de Yeste, Alonso del Castillo Morote y Miguel del Castillo Morcadas, para enviarlo a Pedro Cebrián. Salvo el primero, los otros tres serían encarcelados por negarse a tal menester ${ }^{23}$.

Para hacer efectivo el cese de Cebrián, se envió un peón, que le

\footnotetext{
${ }^{18}$ Ibídem. Sesión del 30-XII-1556. Fols. 203ro-204ro․

${ }^{19}$ Ibídem. Sesión del 3-II-1557. Fol. 204vo․

${ }^{20}$ Ibídem. Sesión del 17-IX-1557. Fol. 233ro.

${ }^{21}$ Ibídem. Sesión del 17-IX-1557. Fol. 233rํ- 233ro

${ }^{22}$ Ibídem.

${ }^{23}$ Ibídem. Sesión del 17-IX-1557. Fol. 233ro․
} 
entregó "la rrevocaçión que lleva para que se venga"24; y también un vecino de Villamalea le llevó otra anulación del mismo poder ${ }^{25}$ con tal de asegurar la comunicación. Lo cual demuestra la enconada determinación del concejo de apartarle del cargo.

La confianza que se tenía en el anterior solicitador Alonso Hernández, padre del actual, era más que evidente. Los pagos que debía efectuar el mayordomo del concejo al hijo, eran depositados primero en su progenitor, para que éste, a su vez, se los enviase. Los libramientos van referidos al salario, a veces mezclados con los correspondientes a gastos de pleitos, "pagad a Pedro Çebrián, nuestro soliçitador en Granada, e Alonso Hernández, su padre, para que los enbíe, veinte ducados"26.

En la cuentas de propios de 1556-1557 quedaba reflejada la liquidación de los negocios del solicitador, habiendo de librarle 84.859 maravedís (casi 2.500 reales).

[...] a Pedro Çebrián e Alonso Hernández, su padre, o a qualquier dellos, ochenta e quatro mill e ochoçientos e çinquenta e nueve marauedís que se le deven del alcançe que hizo al conçejo del tiempo questuvo en la çiudad de Granada por soliçitador desta villa en el pleito de los Alfaros sobre hidalguía y en los pleitos contra el duque de Escalona e las villas de Xorquera, Alcaraz e Ves sobre el aprovechamiento de los términos, de lo qual l'está tomada quenta en los libros del ayuntamiento desta villa ${ }^{27}$.

Sin embargo, esas cuentas, o serían revisadas y se descubriría que el balance era a favor del concejo, o realmente no se había realizado el remate final de las mismas. Después se descubrió que quien había manipulado todo el dinero durante la gestión de Pedro Cebrián había sido su progenitor y no él. El propio Cebrián, cuando se vio alcanzado y debía devolver al concejo 15.840 maravedís, "contradixo las quentas diziendo que no rreçebía él [el] dinero, sino el dicho su padre. Por tanto, atento quel dicho su padre rreçebió el dinero e dio cartas de pago dello, que lo mandavan e mandaron poner en la cárçel hasta que aia pagado el dicho alcançe"28.

Así pues, el hijo no era responsable de ese débito. Aún en abril del año 1559, estaban las operaciones sin liquidar, pues los oficiales del

${ }^{24}$ A.H.P. de Albacete. Secc. Municipios. Caja 4578. Libro 228. Cuentas de propios 1552-1564. Cuenta del 29-IX-1556 a 29-IX-1557.

${ }^{25}$ Ibídem.

26 Ibídem. Cuenta del 29-IX-1555 a 29-IX-1556.

${ }^{27}$ Ibídem. Cuenta del 29-IX-1556 a 29-IX-1557.

${ }^{28}$ A.H.P. de Albacete. Sec. Municipios. Caja 4507. Actas capitulares 1552-1562. Sesión del 3-VIII-1558. Fols. 280ro-280vo․ 
ayuntamiento "mandaron al procurador del conçejo que pida a Alonso Hernandes el alcançe de quentas de su hijo Pedro Çebrián, e que dé aprobaçión de su hijo de las quentas" 29 .

Sólo una parte del dinero que el concejo entregaba a Hernández, era enviada por éste a su vástago, según se deja ver en la sesión del ayuntamiento del 11 de octubre de 1561. Pues ese "Alonso Hernandes, su padre, cobró muncha cantidad de dinero de los salarios para los enviar al dicho Pedro Çebrián, en más cantidad de lo que montaron los salarios y dineros que le fueron tomados al dicho Pedro Çebrián, e no quiso açetarlas ni tomar en quenta lo que tenía rreçebido su padre ${ }^{30}$. Es decir que el ascendiente libraba al descendiente lo imprescindible para la gestión de solicitador en Granada, reteniendo para sí lo restante del total que previamente había recibido del consistorio.

No nos consta que en 1558 y 1559 hubiese solicitador en Granada. En 1560 se vio la necesidad de nombrar otro, pues el pleito sobre la hidalguía de los Alfaro estaba desatendido, y la parte contraria seguía figurando como hidalgos por no haberse sacado la ejecutoria que los sentenciaba por pecheros, "y para otros pleitos questa villa tiene con la villa de Ves y el duque d'Escalona, conviene enbyar soliçitador"31. Se nombró a Esteban Pérez, a la vez que se le enviarían fondos para que pagase a los letrados ${ }^{32}$.

Una vez ajustadas las cuentas con los abogados, el nuevo solicitador había pedido el dinero correspondiente para hacerles la liquidación. En noviembre del mismo año 1560, Pérez indicaba que se debían más de cien ducados a letrados y procuradores. Pero, de momento, sólo le mandaron algo más de la mitad, 600 reales, prestados por el alférez Pedro Carrasco, durante quince días. En caso de no serle devuelto en ese tiempo, se habría de vender trigo del año anterior para sufragar el préstamo ${ }^{33}$. Un peón fue a Granada a llevar ese capital, ocupándose quince días en el viaje y estada ${ }^{34}$.

Una vez que hubo vuelto a Albacete, el solicitador Esteban Pérez cobró "sesenta y vn mill y ochenta y dos marauedís que se le deven de zien días que se a ocupado por soliçitador desta villa en la çiudad de Granada",

\footnotetext{
${ }^{29}$ Ibídem. Sesión del 1-IV-1559. Fol. 299voo.

30 Ibídem. Sesión del 11-X-1561. Fol. 388oㅜ

${ }^{31}$ Ibídem. Sesión del 3-IX-1560. Fol. 347roํ.

${ }^{32}$ Ibídem. Sesión del 3-XI-1560. Fol. 354vo․

${ }^{33}$ Ibídem. Sesión del 27-XI-1560. Fols. 355vo-356ro

${ }^{34}$ A.H.P. de Albacete. Secc. Municipios. Caja 4578. Libro 228. Cuentas de propios 1552-1564. Cuenta del 29-IX-1560 a 29-IX-1561.
} 
en el pleito de los Alfaros sobre hidalguía, y en el de Jorquera y Ves sobre el aprovechamiento de términos "a ocho rreales cada día". Y otros 23.880 maravedís que pagó de derechos y salarios de letrados ${ }^{35}$.

\subsection{En la Corte de Valladolid}

Hasta que Felipe II decidió trasladarse a Madrid en 1559, y desde el reinado anterior, la Corte estuvo en Valladolid. Aquí se libraban los procesos sobre jurisdicción y todo lo relativo a la incumbencia real. Actuaba como letrado, por parte de Albacete, Andrés Ponce de León y después, a partir de agosto de 1558, el licenciado Núñez de Avedaño.

Como hemos señalado, Tristán Calvete haría las funciones de procurador y solicitador. En las cuentas de propios se reflejan pagos por sus honorarios y salario habitual anual ( 6 ducados) ${ }^{36}$, así como el envío de documentación sobre su gestión y los diversos trámites burocráticos que despachaba ${ }^{37}$. El cargo le sería revocado en octubre 1560, "porque de presente esta villa no tiene neçesidad de procurador en Corte"

Además de Calvete, el ayuntamiento albaceteño tuvo otros solicitadores puntuales en este tiempo. A primeros de octubre de 1555 se constata que el bachiller Alarcón está como tal, entendiendo en el pleito de La Gineta. En un momento determinado, manifiesta su voluntad de dejar el asunto y regresar Albacete, "e que se quiere venir. Que se l'escriva que se venga i que traiga el previllejo, e que se venga sacadas las rrelaçiones" 39 . Dos meses después lo vemos rindiendo cuentas e informando sobre la necesidad de que se nombrase a otro en su lugar, "porque la villa de La Gineta da prisa en el negoçio y está concluso el pleito para verse ${ }^{40}$, a la vez que deja constancia que se tienen pleitos con Las Peñas, El Bonillo y Chinchilla ${ }^{41}$. En las cuentas de 1555-1556 se refleja la liquidación que se le hizo en su favor, "del tiempo questubo por esta villa por soliçitador della en Valladolid"42.

A finales de agosto de 1556, para gestionar el asunto con La Gineta,

\footnotetext{
${ }^{35}$ Ibídem.

${ }^{36}$ Ibídem. Cuenta del 29-IX-1557 a 29-IX-1558.

${ }^{37}$ Ibídem. Cuenta del 29-IX-1558 a 29-IX-1559.

${ }^{38}$ A.H.P. de Albacete. Sec. Municipios. Caja 4507. Actas capitulares 1552-1562. Sesión del 4-X-1560. Fol. 353ro․

${ }^{39}$ Ibídem. Sesión del 3-X-1555. Fols. 162vํㅡ-163ํㅡ․

${ }^{40}$ Ibídem. Sesión del 31-XII-1555. Fols. 166roํ-167roํ.

${ }^{41}$ Ibídem. Sesión del 30-XII-1556. Fols. 203ro-204ro .

${ }^{42}$ A.H.P. de Albacete. Secc. Municipios. Caja 4578. Libro 228. Cuentas de propios 1552-1564. Cuenta del 29-IX-1555 a 29-IX-1556.
} 
se había enviado como solicitador al regidor Francisco de Villena. Algunos miembros del concejo no estaban de acuerdo con su competencia. En presencia de Alonso Gómez, alcalde mayor del Marquesado, Jorge de Alcañavate reprochaba la baja calidad social de su homólogo para cumplir la misión,

[...] porque para el dicho pleito es menester vna persona mui abonada e de muncha confiança, y quél no tiene confiança. Quel dicho Françisco de Villena hará el negoçio qual convenga a esta villa porques vn onbre pobre; así mismo, que no tiene qué comer y no entenderá en negoçios si no es por su propia grangería e ganar de comer, como se ofreçe a dar informaçión a su merçed dello. I por otras cabsas, que protesta desir y aclarar, pide e rrequiere al dicho sennor alcalde maior e a los demás sennores rregidores, le manden luego se venga, pues el salario que gana es eçesivo atenta la calidad de su persona, con protestaçión que haze quel perjuizio que viniere a esta villa e propios e rrentas della, por estar el dicho Françisco de Villena entendiendo en los dichos negoçios, sea a culpa e cargo de los dichos sennores e no suya ${ }^{43}$.

Días después, el alguacil mayor, vistas las quejas, nombró para el cargo a Antón Martínez de la Gineta. Como en ese momento se trataba el pleito sobre el registro de ganados, se acordó que los cabañeros locales y el concejo diesen, a medias, un salario único al nuevo solicitador ${ }^{44}$.

No obstante, o no se consumó el nombramiento o también permaneció el anterior Villena, pues vemos que éste, en octubre, envió una carta pidiendo al ayuntamiento poder especial para contradecir a La Gineta, que quería tener su propio encabezamiento de impuestos. También solicitaba relación de lo que pagaba esa nueva villa "por las alcavalas del viento e lo que pagan por lo que se rreparte en sus vezinos. E se le enbíen çinquenta ducados para faser sacar las rrelaçiones en lo de La Gineta"45. Incluso, al mes siguiente, el propio concejo acuerda que se le envíen doscientos reales "para contentar los letrados e que trayga los previllejos confirmados e vn çiento inprimidos" ${ }^{\prime \prime 6}$. La causa de la continuidad estaba en su propia negativa a aceptar la destitución. A primeros de diciembre, además de constar que se le han enviado ya dos o tres cartas para que regrese a Albacete, todos los oficiales consideran que se nombre al bachi-

${ }^{43}$ Ibídem. Caja 4507. Actas capitulares 1552-1562. Sesión del 22-VIII-1556. Fol.187ro.

${ }^{44}$ Ibídem. Sesión del 9-IX-1556. Fols. 190ro-191roํ.

${ }^{45}$ Ibídem. Sesión del 19-X-1556. Fols. 195o-196roํ.

${ }^{46}$ Ibídem. Sesión del 7-XI-1556. Fol. 198ro . 
ller Alarcón, tenido en más competencia para esos negocios ${ }^{47}$. No obstante Francisco de Villena se resistía, siendo nuevamente recriminado, pues las diligencias que se le encomendaron estaban algunas ya despachadas y otras estacionadas ${ }^{48}$. El vecino Alonso Pacheco, sería el encargado de ir a notificar al interesado el cese del poder que tenía del concejo ${ }^{49}$ y, ya una vez venido, se le hizo liquidación de sus honorarios, librándole "onze mill marauedís, para en parte del pago de los salarios que a ganado desta villa del tiempo que a sido soliçitador della en Corte, en los pleitos que en ella trata esta villa"s0.

Después sería nombrado puntualmente para el cargo el escribano Miguel Sánchez del Castillo, entendiendo sobre los registros de ganados y otros asuntos, y ocupándose en ello durante setenta y dos días, a ocho reales cada día ${ }^{51}$.

A mediados de agosto de 1558 el ayuntamiento nombró al expresado bachiller Alarcón, "e porque son los pleitos munchos y se an de pagar derechos, mandaron que se libren treinta mill marauedís". Como en ese momento el concejo no tenía ese dinero, se tomaría de las tercias. Al mismo tiempo se trató sobre la situación del letrado que tenía la villa, que había sido destinado por la Corona al gobierno de Nápoles.

[...] que el liçençiado Andrés Ponçe de León es letrado desta villa en Corte y tiene notiçia que Su Magestat lo a proveýdo por rregente de Nápoles. E conviene questa villa tenga letrado en Corte para los dichos negoçios. Encargaron al dicho bachiller Alarcón para que trate con el liçençiado Núnnez de Avendanno, abogado en Corte, que sea letrado desta villa y trate con él el salario que se le a de dar por esta villa y lo asiente con él ${ }^{52}$.

Sin embargo, días después, el alcalde ordinario Alonso de Villanueva de Barrax revocaría el nombramiento del solicitador, alegando que no era necesario, "ni esta villa tiene neçesidad de soliçitador en la Corte por agora, y que tener allá a el dicho bachiller Alarcón es costear a esta villa

\footnotetext{
${ }^{47}$ Ibídem. Sesión del 7-XII-1556. Fols. 201ro-201vo․

${ }^{48}$ Ibídem. Sesión del 30-XII-1556. Fols. 203ro-204rº .

${ }^{49}$ A.H.P. de Albacete. Secc. Municipios. Caja 4578. Libro 228. Cuentas de propios 1552-1564. Cuenta del 29-IX-1556 a 29-IX-1557.

${ }^{50}$ Ibídem.

${ }^{51}$ Ibídem. Cuenta del 29-IX-1557 a 29-IX-1558.

${ }^{52}$ A.H.P. de Albacete. Sec. Municipios. Caja 4507. Actas capitulares 1552-1562.

Sesión del 11-VIII-1558. Fols. 281o-282roํ.
} 
$\sin$ fruto $^{\prime 53}$. El resto de oficiales no debió de apoyar la cancelación, pues el 1 de octubre del mismo año todavía continuaba el bachiller en su cargo, enviando a Albacete correspondencia sobre su gestión ${ }^{54}$. Son varios los libramientos que se hacen al respecto. A un vecino de Chinchilla que le llevó ciertas cartas y trajo unas provisiones. A otro de La Roda por lo mismo. Al albaceteño Francisco Sedeño, que le entregó dinero para parte de pago de sus salarios ${ }^{55}$ y "porque llevó a la Corte çiertas cartas y despachos del conçejo al bachiller Pedro de Alarcón, soliçitador desta villa que está en Corte, e dineros para pagar derechos" ${ }^{\prime 56}$.

En la primavera de 1559 ya parece que el bachiller ha regresado a Albacete, por cuanto el ayuntamiento ordena a su mayordomo, Juan del Cobo, "que no pague dineros ningunos a el bachiller Alarcón hasta que aia entregado todas las escripturas que tiene del conçejo, so pena de los pagar otra vez"57.

A primeros de noviembre de 1560, volvería Sánchez del Castillo a estar ocasionalmente en el cargo, con un salario de ocho reales por cada día que se ocupare, llevando poder e instrucción del concejo para los negocios a tratar ${ }^{58}$. Y, en marzo del año 1561, lo atendía Pablo Hernández, que fue enviado con el fin de que entendiese sobre "lo que se pide que se quiten los rregidores de los propios del conçejo". Enterado el concejo de que el solicitador de La Gineta se había desplazado a la Corte para meter prisa en el pleito con Albacete sobre la jurisdicción, se pide a Hernández que "asista en el dicho negoçio entretanto que se probee en ello lo que conviene $^{\prime \prime 59}$. Este Hernández ejercería su cometido puntualmente y sin consenso concejil en su nombramiento. Al mes siguiente se le pidieron cuentas de su gestión ${ }^{60}$.

\footnotetext{
${ }^{53}$ Ibídem. Sesión del 7-IX-1558. Fols. 284roo-284vo․

${ }^{54}$ Ibídem. Sesión del 1-X-1558. Fol. 289ro․

${ }_{55}^{5}$ A.H.P. de Albacete. Secc. Municipios. Caja 4578. Libro 228. Cuentas de propios 1552-1564. Cuenta del 29-IX-1557 a 29-IX-1558.

${ }^{56}$ Ibídem. Cuenta del 29-IX-1558 a 29-IX-1559.

${ }^{57}$ A.H.P. de Albacete. Sec. Municipios. Caja 4507. Actas capitulares 1552-1562. Sesión del 1-IV-1559. Fol. 299vo.

${ }^{58}$ Ibídem. Sesión del 3-XI-1560. Fol. 354vo․

${ }^{59}$ Ibídem. Sesión del 4-III-1561. Fol. 362o․

${ }^{60}$ Ibídem. Sesión del 21-IV-1561. Fol. 367ro․
} 


\section{CON EL DUQUE DE ESCALONA Y LA VILLA DE VES}

Fueron frecuentes los enfrentamientos con el entonces marqués de Villena, duque de Escalona, señor de Jorquera y Alcalá, y con la villa de Ves. El motivo estaba en la incursión de vecinos de Albacete en esos dominios. Paralelamente, la ciudad de Chinchilla también pleiteaba por lo mismo contra el Marqués. Ya en 1497 los Reyes Católicos solicitaron información al corregidor de Murcia sobre esas desavenencias pues, desde tiempo inmemorial, chinchillanos y albaceteños habían estado en posesión, uso y costumbre de entrar y pacer con sus rebaños en los términos de Jorquera, pagando borra y asadura ${ }^{61}$. Sin embargo los arrendadores del marqués-duque, y con aquiescencia de éste, no les respetaban ese derecho, prendándoles los ganados (Carrilero, 2004, pp. 228-230) y exigiéndoles además el pago del servicio y montazgo ${ }^{62}$. Las controversias siguieron también en los gobiernos de la reina doña Juana (Carrilero, 2002, pp. 71-73) y su hijo Carlos V (Carrilero, 1983, p. 325; 2000, p. 364).

A pesar de las querellas, la propia villa de Ves reconocía en 1575 el privilegio que tenían otros pueblos para herbajar dentro de su término,

porque ay buenas yerbas para los ganados ovejunos y buenos montes para ganados cabrunos,.... Y en los mesmos pastos de los dichos términos tienen hermandad e comunidad para los poder paçer los yezinos de la villa de Alcala del Río y de la villa de Xorquera y su tierra, y tanbién la villa de Albaçete, porque tienen por hexecutoria real (Carrilero, García Moratalla, Cifo, Valdelvira, 2014, p.229).

\footnotetext{
${ }^{61}$ Borra.- Tributo sobre el ganado. Impuesto recaudado inicialmente bajo la forma de "corderas de un año", de las que tomó el nombre. Se generalizó de 1485 a 1490, calculándose en una oveja (no necesariamente una cordera) por cada quinientas.
}

Asadura.- Derecho que se pagaba por el paso de los ganados. Pequeño impuesto que se remonta al siglo $\mathrm{X}$, que en un principio se cobraba bajo la forma de "la asadura de las ovejas o del ganado". Durante la Edad Media se cobró a razón de un cordero o media oveja por rebaño. Sobre este impuesto en el Marquesado de Villena, véase (González, 2002, p. 128).

${ }^{62}$ Servicio y montazgo.- La primera indicación de un impuesto directo a los trashumantes en el siglo XIII se denominó "servicio"; fue la primera renta real impuesta en Castilla, donde la trashumancia de rebaños era usual desde hacía siglos. En 1343 se transformó su nombre en "servicio y montazgo", al incorporarse los montazgos locales (de las tierras de realengo) a la Corona, perdurando su carácter tal y como en su origen lo habían planeado Alfonso X y sus agentes fiscales. Era un ingreso permanente y pagadero anualmente a la realeza. No debe confundirse con el montazgo local. Véase (González, 2002, p. 121). 
Aunque estos litigios se resolvían en Granada, un receptor real, Luis Vázquez de Acuña fue el encargado de trasladarse a tierras del Marquesado de Villena para obtener todas las declaraciones y pruebas que habrían de conducir a la resolución del conflicto en la Audiencia. Del mismo modo, las partes debían presentar sus testigos correspondientes ante ese receptor, con los consiguientes gastos para el concejo. Así, se reflejan pagos que se hicieron a un vecino de Chinchilla que se ocupó siete días en ir a declarar al lugar de Montalbanejo, donde se encontraba Acuña, sobre la probanza que Albacete hacía contra Ves del aprovechamiento de términos. Otro chinchillano fue a la villa de Barchín a lo mismo. A un vecino de Albacete se le libraron 15 reales por cuatro días que empleó en ir a llamar a un testigo a Elche para idéntico asunto. Otro fue compensado porque fue a Sax a cobrar 5.000 maravedís que se le debían al concejo "de los gastos questa villa a hecho en el pleito con el duque de Escalona e villa de Jorquera e Ves" y de llevar una carta al corregidor sobre el pleito de la taja. Y otros que fueron a Barrax y a Carcelén por motivos del mismo conflicto ${ }^{63}$.

También el procurador del concejo, Miguel Sánchez, recibió 75 reales por ir a Barrax a buscar un testigo para el pleito de Ves, y por siete días que empleó en "yr a la villa de Montalbanejo y Barchín, a donde estaba Luis Bázquez de Aqunna, rreçebtor", para presentar ante él, por testigos, a dos vecinos de Chinchilla, a uno de Jorquera y a otro de Campillo, a los que, a su vez, tuvo que remunerar. Este procurador estuvo treinta y cinco días buscando al receptor para que viniese a acabar la probanza de Ves. También lo buscaría otro peón albaceteño, que lo encontró en el Castillo de Garcimuñoz. Nos consta que vino, pues el ayuntamiento libró cinco reales a dos hermanos, vecinos de La Gineta, por testimoniar ante él sobre el aprovechamiento del término, así como tres reales y medio al peón que fue a llamarlos. Está claro que esos informantes eran favorables a la postura albaceteña al respecto, incluso sabemos que eran preparados para declarar a su favor, como Juan López Cañavate, vecino de Alcalá, que anduvo tres días, junto con el procurador de Albacete, "por çiertos pueblos a encaminar los testigos para la probança questa villa haçía contra Bes sobre la comunidad de los términos" ${ }^{\prime \prime 4}$.

En las declaraciones y pesquisas hechas ante el receptor real, además de los testigos, estaba también presente el procurador de Albacete, que cobraba sus honorarios. Miguel Sánchez recibió 13.325 maravedís

${ }^{63}$ A.H.P. de Albacete. Secc. Municipios. Caja 4578. Libro 228. Cuentas de propios 1552-1564. Cuenta del 29-IX-1554 a 29-IX-1555.

${ }^{64}$ Ibídem. 
"de los días que se ocupó con Juan de Mosquera e Luys Bázquez, rreçebtores de Su Magestat", haciendo las probanzas del pleito con Ves sobre la taja, y otros que se seguían con La Gineta y los Alfaros, como veremos. Igualmente, al expresado Vázquez de Acuña, se le libraron 30 ducados en parte del pago de su gestión en el pleito de Ves por los términos, por la taja en Jorquera y en el de los Alfaros ${ }^{65}$.

Una vez hechas las probanzas ante ese mandatario real, eran enviadas a la Real Audiencia de Granada. El mensajero Antonio de Sesma, cobró ducado y medio por llevar a esa ciudad las relativas al aprovechamiento de términos en Ves y en poblaciones del Marqués. También se ocasionaban gastos por el trámite del asunto en la propia Chancillería. El bachiller Francisco de Cantos recibió cincuenta ducados por ir como solicitador, para entender sobre lo dicho en aquellos lugares, además del pleito de los Alfaros y otros negocios. Una vez allí, el concejo le enviaría veinte ducados más. Otros vecinos aceptaron honorarios por lo mismo, como Juan Jiménez de Cubas, por ir allí a buscar una compulsoria "para sacar çiertas escrituras de lo tocante al pleyto de Bes". Otro, llamado Juan Perlado, fue a traer ciertos testimonios y prorrogación en los pleitos y probanzas contra el duque de Escalona, pagándole, previo acuerdo, sólo la mitad de lo habitual, "porque llebó otros despachos de otras personas"

En cuanto a la parte del marqués de Villena, encontramos que en 1556 la Chancillería de Granada había dictaminado en su contra, con dos ejecutorias a favor de Albacete, por las cuales se pagaron seis reales a Martín Serrano, vecino de Villanueva de la Jara, "porque truxo çiertas provisiones e despachos e dos executorias de Granada sobre la comunidad de los términos con Xorquera"67. Una de ellas versaba sobre unas reses que se habían tomado al albaceteño Juan del Campillo; y la otra era relativa a los derechos de borra, taja y asadura en el término de Jorquera. Ambas estaban en poder del abogado Francisco Gallego, que fue llamado por el concejo, "para ver lo que se a de faser sobrellas"68. El letrado aconsejaba que para poder actuar sobre la devolución de las reses, necesitaba poder del propio Campillo. Sería primero el regidor Francisco de Villena quien se ocuparía cinco días en ir a requerir sobre el asunto al referido señor de Jorquera. Después, fue el procurador Miguel Sánchez a notificar que se le devolviesen al vecino señalado las 48

\footnotetext{
${ }^{65}$ Ibídem.

${ }^{66}$ Ibídem.

${ }^{67}$ Ibídem. Cuenta del 29-IX-1555 a 29-IX-1556.

${ }^{68}$ A.H.P. de Albacete. Sec. Municipios. Caja 4507. Actas capitulares 1552-1562.

Sesión del 9-IX-1556. Fols. 188vo- 189roo.
} 
ovejas que le tomaron "contra el derecho desta villa". También se desplazó a San Clemente a hacerle saber lo mismo "a Luis de Luçón, maiordomo que fue del Marqués" 69.

Respecto a la otra ejecutoria, tocante al impuesto sobre el ganado, sabemos que, en 1556, los albaceteños debían contribuir en tierra de Jorquera con un tanto por cada animal. No obstante, el caballero de la sierra jorquerano, Francisco Fernández, "contra la dicha executoria, avía tomado çiertas cabeças de ganado a vezinos desta villa (de Albacete)". El abogado Gallego requería que se llamase a los perjudicados para que declarasen cuántas cabezas les habían sido requisadas a cada uno, con tal de que, una vez hecha la averiguación, el receptor real ejecutase en la parte contraria "según e como debe". Y, en su caso, los vecinos de Albacete "paguen sesenta marauedís de la taja de cada rres que le fue tomada por ello"70.

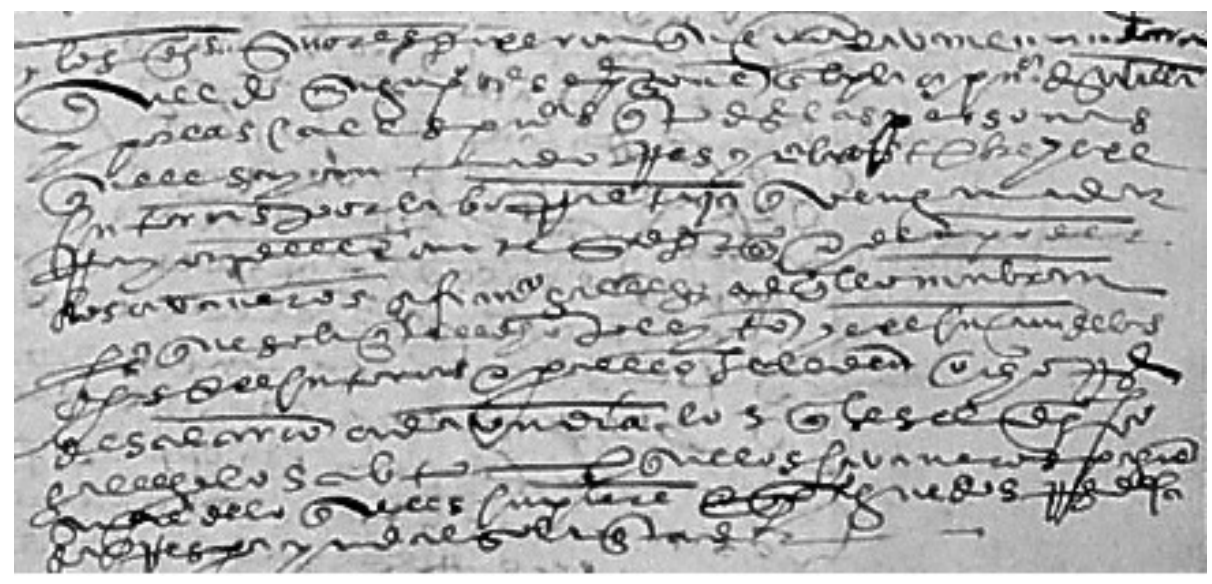

Fragmento original de la transcripción posterior (Fol. 189rº).

Los dichos sennores dixeron que mandavan e mandaron quel domingo primero viniente se pregone en la plaça pública desta villa, y por las calles públicas, que todas las personas que les aian tomado rres contra la costunbre y executoria, por la borra e taja, que vengan a dar rrazón dello ante mí dicho escriuano. E den poder, los cavanneros, a Françisco Gallego, a el qual lo nonbran para que soliçite el dicho pleito i execuçión de las dichas executorias. E, para ello, se le den ocho rreales de salario cada vn día. Los quales el dicho Françisco Gallego los

${ }^{69}$ Ibídem. Caja 4578. Libro 228. Cuentas de propios 1552-1564. Cuenta del 29-IX1555 a 29-IX-1556.

${ }^{70}$ A.H.P. de Albacete. Sec. Municipios. Caja 4507. Actas capitulares 1552-1562. Sesión del 9-IX-1556. Fols. 188vo-- 189roํ. 
açebtó. E que los cavanneros paguen su parte de lo que les cupiere, e paguen dos rreales de cada rres para aiuda al soliçitador ${ }^{71}$.

Sin embargo, de momento, los de Jorquera no cumplirían las ejecutorias, por cuanto Juan Perlado, vecino de Albacete, se desplazó a Granada a llevar dinero al solicitador "y a llevar çiertos testimonios que se sacaron contra la justiçia de Xorquera por no aver querido conplir la executoria sobre la comunidad de términos ${ }^{\prime 72}$. Ante esa negativa, sería necesaria la presencia del receptor real que ordenase de facto su acatamiento. Por ir a buscarlo, se adelantaron al abogado Gallego treinta reales. Al no ser hallado, primero el afectado Juan del Campillo rastreó por zonas próximas a Albacete $^{73} \mathrm{y}$, a finales de mayo de 1557, se acordó enviar un mensajero a San Clemente, donde se creía que hallaba, a rogarle que compareciese a resolver el asunto ${ }^{74}$. Tampoco se daría con él pues, días después, se ordenó ir "a buscar vn rreçetor por la comarca para executar las executorias contra Xorquera e Alcalá. Y si no se hallare, se tome testimonio y se enbíe a Granada para que manden venir rreçetor $^{\prime \prime 5}$. Se encontraba en tierras murcianas, según se desprende del libramiento que se le hizo a un peón que llevó una carta y otros despachos "a Pedro Ximenes, rreçebtor de la Chançillería de Granada, que viniese a executar las cartas executorias que tiene desta villa contra Xorquera e Alcalá". Tampoco vendría, pues aún fue después tras él otro vecino, llamado Alonso Pacheco, que lo halló en Vélez Blanco, recibiendo promesa de que vendría a realizar su cometido, "e truxo carta del dicho rreçebtor que vendrá con brevedad"76.

A finales de julio ya se encuentra en Albacete, "que en esta villa está vn rreçetor que viene a hexecutar las hexecutorias contra la villa de Xorquera e Alcalá' ${ }^{\prime 7}$, y el ayuntamiento nombra al escribano Juan Berruga para que le acompañe mientras vaya llevando a cabo las ejecutorias en esas poblaciones ${ }^{78}$. Diversos libramientos dan prueba de que se estaba entendiendo en el asunto. El propio Berruga se ocupó

\footnotetext{
${ }^{71}$ Ibídem. Fol. 189ro․

${ }^{72}$ Ibídem. Caja 4578. Libro 228. Cuentas de propios 1552-1564. Cuenta del 29-IX1555 a $29-I X-1556$.

${ }^{73}$ Ibídem. Cuenta del 29-IX-1556 a 29-IX-1557.

${ }^{74}$ A.H.P. de Albacete. Sec. Municipios. Caja 4507. Actas capitulares 1552-1562. Sesión del 24-V-1557. Fol. 214ํo.

${ }^{75}$ Ibídem. Sesión del 5-VI-1557. Fol. 220roํ.

${ }^{76}$ A.H.P. de Albacete. Secc. Municipios. Caja 4578. Libro 228. Cuentas de propios 1552-1564. Cuenta del 29-IX-1556 a 29-IX-1557.

77 A.H.P. de Albacete. Sec. Municipios. Caja 4507. Actas capitulares 1552-1562. Sesión del 24-VII-1557. Fol. 223roo.

${ }^{78}$ Ibídem. Sesión del 26-VII-1557. Fol. 223vo․
} 
catorce días en las probanzas de borra, taja y asadura. También el receptor Pedro Jiménez recibiría sus honorarios ${ }^{79}$, pues en agosto todavía seguía tratando el mismo negocio, señalándose el tiempo que había empleado en ello, "treynta y nuebe días, y tres días desde la çibdad de Murçia a esta villa, que son por todos quarenta y dos días. Y que acabado el negoçio se hará quenta y se aberiguará". Por su parte, el escribano Berruga se encargaría de cobrar a los vecinos de Albacete los sesenta maravedís por cabeza de ganado, correspondiente a la taja, según rezaba en la ejecutoria, "y en ello se a oqupado beynte días" 80 .

En enero de 1558, el consistorio albacetense enviaría a Murcia al procurador Miguel Sánchez a hacer efectivas las reales ejecutorias presentadas ante el receptor, que en esa fecha ya había fallecido ${ }^{81}$. Se le hizo por ello libramiento de 99 reales,

los noventa y ocho de catorze días que os ocupastes en yr a la çibdad de Murçia a llevar la paga del serviçio, y a la villa de Alcantarilla a cobrar la execuçión de la taja contra Jorquera, que estava en poder de Pedro Ximenes, rreçetor defunto; e syete rreales cada día, e vn rreal que pagastes de vn testimonio de cómo hera muerto el rreçevtor ${ }^{82}$.

También hubo querella con Jorquera por el registro de caballos. En julio de 1561 se envió a Granada el proceso porque, además de ese obligado asiento, se exigían fianzas ${ }^{83}$. El corregidor jorquerano tomaba equinos a los albaceteños "avnque llevan rregistro, diziendo no llevar fianças". Esto resultaba ser algo novedoso porque "nunca se a pedido más de llevar rregistro, fecho ante la justiçia y escribano". Todo estaba motivado porque, por aquel entonces, se había requisado uno de esos animales a Alonso Morote, vecino de Albacete, teniéndolo reconocido como lo tenía, y el concejo recurrió ante la Chancillería de Granada, "porques cosa que muncho inporta al derecho desta villa"84.

Otro enfrentamiento fue el relativo al aprovechamiento de rastro-

\footnotetext{
${ }^{79}$ A.H.P. de Albacete. Secc. Municipios. Caja 4578. Libro 228. Cuentas de propios 1552-1564. Cuenta del 29-IX-1556 a 29-IX-1557.

${ }^{80}$ A.H.P. de Albacete. Sec. Municipios. Caja 4507. Actas capitulares 1552-1562. Sesión del 28-VIII-1557. Fol. 227ro .

${ }^{81}$ Ibídem. Sesión del 20-I-1558. Fol. 252vº.

${ }^{82}$ A.H.P. de Albacete. Sec. Municipios. Caja 4578. Libro 228. Cuentas de propios 1552-1564. Cuenta del 29-IX-1557 a 29-IX-1558.

${ }^{83}$ Ibídem. Caja 4507. Actas capitulares 1552-1562. Sesión del 26-VII-1561. Fol. $378 v^{0}$.

${ }^{84}$ Ibídem. Sesión del 23-VIII-1561. Fol. 382roo.
} 
jos. El ayuntamiento de Jorquera había establecido unas ordenanzas que prohibían la intromisión de ganados foráneos en sus tierras segadas. Por ello, había prendado reses a los hermanos Francisco y Juan Felipe, vecinos de Albacete, "siendo pasto común, e tienen desta villa executoria para los poder gozar e paçer con sus ganados". El concejo albaceteño tomó para sí el pleito, por ser en perjuicio de los dos agraviados y de su lugar de origen ${ }^{85}$. A finales de mayo de 1560 el consistorio expresaba el deseo de defender la causa en la Chancillería de Granada, y que se trajese "enplazamiento e conpulsoria para llevar el proçeso"s6. En agosto del mismo año queda constancia de que se apeló de la sentencia contra esos vecinos.

[...] En días pasados se apeló de çierta sentençia dada por la justiçia de Xorquera contra Françisco Helipe, vezino desta villa, de çiertas rreses que le tomaron en perjuizio del derecho questa villa tiene de paçer las iervas e beber las aguas de los términos de la dicha villa de Xorquera. Y está sacado el proçeso y çitada la parte. Mandaron que luego vaya vn mensajero y lleve el proçeso y enplazamiento i se escriba al procurador del conçejo questá en Granada para que siga la cabsa ${ }^{87}$.

El emplazamiento y compulsoria los traería el vecino Andrés Díaz, el cual se ocupó trece días, con ida, venida y estada. Además, se quejarían los albaceteños ante la Corte, pidiendo sobrecarta de sus derechos. Hasta allí había sido enviado Gregorio Martínez, para pedir "vna provisión sobre el paçer los ganados desta villa los rrestrojos del término de la villa de Xorquera". Una vez que la provisión estuvo en Albacete, se envió a Jorquera para que quedase notificada allí.

[...] Pagad a Benito Pérez el moço, vezino desta villa, quarenta e vn rreales que a de aver, los treinta e çinco rreales que ganó de salario por çinco días que se ocupó en yr a la villa de Xorquera a hazer notificar vna rreal provisión hemanada del Consejo de Su Magestat, sobre çiertas hordenanças que an fecho el conçejo de la dicha villa de Xorquera açerca del penar en los rrestrojos, para que enbiasen las dichas hordenanças al Consejo de Su Magestat dentro de çierto término; y los seis rreales que los pagó de derechos a Ginés de Rródenas, escriuano de Xorquera, de notificar la dicha rreal provisión, de que truxo carta de pago ${ }^{88}$.

${ }^{85}$ A.H.P. de Albacete. Secc. Municipios. Caja 4578. Libro 228. Cuentas de propios 1552-1564. Cuenta del 29-IX-1559 a 29-IX-1560.

${ }^{86}$ A.H.P. de Albacete. Sec. Municipios. Caja 4507. Actas capitulares 1552-1562. Sesión del 25-V-1560. Fol. 329ro.

${ }^{87}$ Ibídem. Sesión del 12-VIII-1560. Fols. 339vo-340ro.

${ }^{88}$ A.H.P. de Albacete. Secc. Municipios. Caja 4578. Libro 228. Cuentas de propios 
Ya hemos señalado que estos conflictos, con el duque de Escalona y sus tierras de Jorquera y Alcalá, así como con la villa de Ves, fueron gestionados en la Chancillería de Granada, a través del solicitador Pedro Cebrián, el procurador Miguel Sánchez y el abogado Francisco Gallego. Éste, a su vez, se encargó de establecer contacto con el receptor para llevar a cabo las ejecutorias sobre la taja, borra y asadura ${ }^{89}$.

\section{DISPUTA DE TÉRMINOS CON CHINCHILLA Y LA GINETA}

En noviembre de 1375 don Alfonso de Aragón, primer marqués de Villena, otorgó el privilegio de villazgo a Albacete, hasta entonces aldea de Chinchilla. Le daría término con jurisdicción propia, aunque podía seguir disfrutando del aprovechamiento y comunidad de pastos de las tierras a las que antes perteneció. Tomando como eje central el Camino Real, se establecía una legua a cada lado de la vía, desde el límite de Alcaraz y La Roda hasta la cuarta parte de la distancia que separaba Albacete de Chinchilla, formando un rectángulo. Tras las protestas de los chinchillanos y varios enfrentamientos, el término estuvo sin delimitarse hasta la sentencia arbitral del obispo de Cartagena, don Pablo de Santamaría en 1414. Ante la duda de qué modelo de legua aplicar, don Pablo eligió una legua ideal, que sería la quinta parte de la distancia de Albacete a Pétrola, que mediría 376 sogas y tres estadales y medio. También se establecía cómo empezar a medir a cada lado del dicho camino desde la misma villa albaceteña. Si se calculaba desde el centro de la población, la anchura de la franja sería de dos leguas. Si se calculaba desde las orillas, serían dos leguas y ciento cincuenta pasos. Esta última fue la medida determinada por el obispo. La figura formada estaba orientada en dirección noroeste, cuyos lados menores estarían cortados por el Camino Real. La altura derecha se situaría a media legua entre Albacete y Chinchilla, y la izquierda estaría entre La Gineta y La Roda (Pretel, 1986; 2010, pp. 338-357; 2020, pp. 90-91).

Dentro del término de Albacete se incluía el del lugar de La Gineta, cuyo territorio había sido asignado por Don Juan Manuel en 1337, donde ya se señalaban sus dimensiones, "hasta el rrío dos leguas, que atrauiessa derecho al chopo, y que sea monxón el rrío ayusso el Atalaya Ballonguer. Y contra Albaçete vna legua, esso mismo en rrededor" (Carrilero, 1987, p. 88). La Gineta se había convertido en villa, eximiéndose de Albacete, por privilegio real otorgado en diciembre de 1553. Se iniciaría desde ese momento un pleito entre ambos lugares, principal-

1552-1564. Cuenta del 29-IX-1559 a 29-IX-1560.

${ }^{89}$ Ibídem. Cuenta del 29-IX-1556 a 29-IX-1557. 
mente por razón de términos, y por otros diversos asuntos colaterales (Carrilero, 1987, pp. 85-94).

En el inicio del conflicto, en 1554, el alcalde mayor del Marquesado, doctor Cordobés, consultó a los interesados y la documentación de la última revisión de mojones llevada a cabo por al alcalde mayor licenciado Graciano Sánchez. El procurador albaceteño, Miguel Sánchez, mostró disconformidad por la intervención de Cordobés en el asunto, instándole a que se acompañase de letrado, porque "la dicha villa mi parte, e yo en su nonbre, tenemos por sospechoso a vuestra merçed, e por tal lo rrecuso en nonbre de mi parte; e juro a Dios esta sennal de cruz que esta rrecusaçión no la hago de maliçia, syno porque así conviene al derecho de mi parte". Por otro lado, La Gineta apremiaba al mismo alcalde mayor a que iniciase de inmediato el amojonamiento definitivo entre las dos villas, pues una cédula real daba un plazo de doce días para que renovase y empinase los mojones, "y queda breve término para la execuçión y cunplimiento de lo susodicho". Albacete alegaba, entre otras cosas, que ella era una población de mucha vecindad, de las principales del Marquesado de Villena y que se quedaría con muy poco término, "que puede ser hasta quatro leguas en largo e dos en ancho, e lo que pide La Gineta es más de la mitad en cantydad y más de quatro tantos en calidad". Además, el procurador Sánchez argüía que el privilegio de villazgo concedido a la Gineta en 1553, no especificaba la extensión del término, "no fue pedido término de nuevo", aunque se entiende claramente que se le da jurisdicción sobre lo que ya le había concedido don Juan Manuel y que estaban amojonados en el momento de la concesión del villazgo, entrando también las aldeas y heredamientos de La Grajuela, El Aljibarro, Brocas de Peña, la Casa de Alonso del Castillo, la Casa de Benito de Molina, y la de Miguel Sánchez del Castillo (Carrilero, 1987, p. 90). Estos dos últimos personajes, destacados en el concejo de Albacete (regidor y escribano respectivamente), eran parte interesada en las reclamaciones ante el doctor Cordobés para que sus haciendas quedasen dentro de la jurisdicción albaceteña. Por lo tanto, correspondería a cada villa más o menos la mitad de lo que hasta entonces estaba bajo la jurisdicción de Albacete, es decir un cuadrado de dos leguas de lado para cada una, según expresaba el procurador albaceteño, aunque, como hemos visto, se quejaba de la mejor calidad del terreno que correspondía a La Gineta.

Efectivamente, Cordobés se acompañó del licenciado Perona, vecino de San Clemente, dejando el caso sin resolver hasta tanto que, previo informe, el rey determinase sobre el asunto ${ }^{90}$.

En las Relaciones de Felipe II, en diciembre de 1575, queda expresado

${ }^{90}$ A.M. de San Clemente. Corregimiento. Leg. 44/48. 
respecto a La Gineta: "A los quarenta e çinco capítulos, aclararon questa villa tiene vna legua de término en torno, que son dos leguas de travieso por cada parte" (Carrilero et al., 2014, p. 109). Es decir un cuadrado de dos leguas de lado. Hubo tres sentencias al respecto en 1568, 1569 y la definitiva de 1579, en la que el Consejo Real establecía el amojonamiento final que separaba los términos de ambas villas (Carrilero, 1987, p. 94).

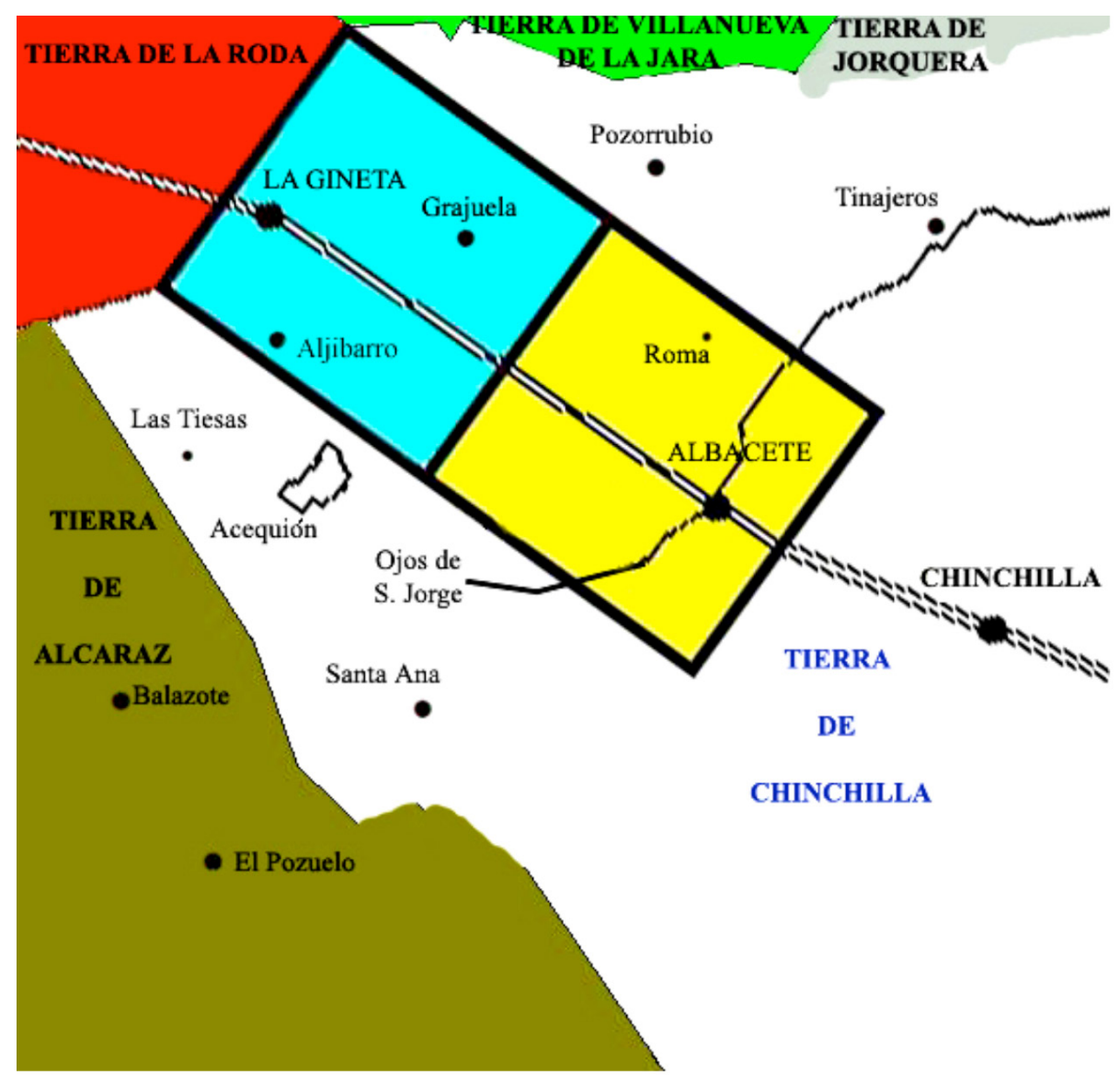

Términos de Albacete y La Gineta hacia 1555. (Plano aproximado elaborado por el autor).

A comienzos de 1566, el concejo de Albacete decidió enviar al regidor Jorge de Alcañavate a solicitar a la Corte la ampliación de su territorio a costa del de Chinchilla ${ }^{91}$. En mayo de 1568, el consistorio daría el visto bueno

${ }_{91}^{91}$ A.H.P. de Albacete. Sec. Municipios. Caja 4508. Actas capitulares 1562-1569. Sesión del 21-II-1566. Fol. 103ํo. 
a lo negociado al respecto por ese oficial ${ }^{92}$, aunque, por las dos leguas que le son concedidas, le parece excesivo el precio de quince mil ducados, comunicando a Alcañavate que lo negocie por diez u once mil ${ }^{93}$. Respondería éste que la ampliación de esas dos leguas vulgares tenía un precio ahora de 16.000 ducados, pero que las condiciones eran "mui ynportantes e provechosas". Las heredades que quedasen dentro del término nuevo que se concediere, podrían hacer vecindad en Albacete "o en los pueblos que quisieren, sin questén neçesitados a haser vezindad en la çibdad de Chinchilla ni en otra qualquier parte donde tenían obligaçión". Y si se llegaba al acuerdo de pagar esa cantidad, "la çibdad de Chinchilla no sea oýda ni admitida para hazer contradizión". El concejo albaceteño daría el visto bueno definitivo para la compra, solicitando las correspondientes provisiones reales para que "se pueda rrepartir entre los vezinos e hazer dehesas y arrendarlas hasta que se aya sacado la dicha cantidad ${ }^{\prime 94}$.

\subsection{Consecuencias de la separación de términos}

La emancipación y delimitación de nuevas demarcaciones afectó de hecho al régimen jurisdiccional. Sin embargo las zonas separadas continuarían disfrutando del aprovechamiento común. Esta circunstancia daría lugar a conflictos que se alargarían en el tiempo.

\subsubsection{Con Chinchilla}

Tras su independencia de Chinchilla, Albacete continuó disfrutando del resto de los territorios de la ciudad. A comienzos del siglo XVI, se corrobora que el pleito entre los dos lugares por motivo de ese beneficio ya venía de antiguo. Los albaceteños se quejaban de que los chinchillanos adehesaban los campos de uso común, prendían los ganados que entraban en ellos, hacían donaciones de tierras a su antojo, les vedaban cazar y cortar leña, etc. Por ello fueron condenados a quitar las dehesas que habían hecho nuevas y todo lo ensanchado a las antiguas, para que el concejo y vecinos de Albacete pudiesen cortar, "e corten, todas las lennas para qualesquier cosas, e tanbién para carretas e aradas en los dichos términos de Chinchilla". Además de hacer carbón, aunque no para vender, sino para su uso, guardando las ordenanzas chinchillanas. En caso contrario, podrían ser juzgados y condenados por esa justicia (Carrilero, 2000, pp. 450-471).

A mediados de siglo, en mayo de 1555 , el emperador Carlos V, a petición de Albacete, solicitaba al concejo de Chinchilla que enviase al Consejo Real un traslado de las nuevas ordenanzas. En ellas se rebaja-

\footnotetext{
92 Ibídem. Sesión del 4-V-1568. Fol. 211o․

${ }^{93}$ Ibídem. Sesión del 15-V-1568. Fol. 214ro.

${ }^{94}$ Ibídem. Sesión del 29-V-1568. Fols. 219ro-219vo․
} 
ban las penas a quienes adehesaban y cercaban terrenos, con el consiguiente perjuicio a los albaceteños, que no podrían entonces aprovecharse de ellos, "porque con vajarse las penas questavan puestas por las dichas hordenanças antiguas, no abría nynguno que no holgase de pagar seisçientos maravedís por hazer los dichos çercados" (Carrilero, 2000, pp. 433-434).

Las quejas fueron frecuentes. En junio del mismo año, Diego de Castañeda pidió al consistorio que le defendiese en una causa que contra él había presentado la ciudad vecina, alegando que, siendo él alcalde ordinario, defendió a ciertos vecinos contra los caballeros de la sierra chinchillanos. Además, por considerarlo injusto, soltó de la cárcel a ciertos presos que el alcalde mayor del Marquesado había mandado prender. "E por obrar como obró, como buen vezino, la dicha çibdad le tiene grande odio y a quexado dél en la çibdad de Granada ante los cabildos del crimen della". Se acordó que se siguiese la causa, llevando instrucción de ello al procurador y solicitador de turno ${ }^{95}$.

A comienzos de 1556, una ejecutoria de la Corte ordenaba al gobernador del Marquesado de Villena que procediese contra Chinchilla, pues tres años antes uno de sus caballeros de la sierra había detenido y puestos presos a cinco albaceteños que cortaron doscientas ramas de carrasca para hacer rayos de carro, junto a La Serilla y el Pozo la Graja, hacia las Pozas de Cañada Pajares (Carrilero, 2000, pp. 446448).

Los enfrentamientos entre los dos lugares por el aprovechamiento común de tierras continuarían en lo sucesivo. En las cuentas de propios de 1559-1560 queda reflejado el libramiento al procurador García Hernández de Córdoba, por un día que se ocupó en ir a Chinchilla a entender en "las prendas que se le tomaron a Benito López, yerno de Pardo", vecino de Albacete, "porque dezían que avía cortado çierta madera en los términos de Chinchilla". Recíprocamente, los de la vecina ciudad se habían presentado ante el alcalde mayor, licenciado Estrada, solicitando que todos los ganados forasteros que se registrasen en ella, pudiesen herbajar en tierra albaceteña. Estrada había contestado al concejo chinchillano sin tener en cuenta la opinión de la villa afectada, "sin la oýr". Por ello, García Hernández se desplazó hasta La Gineta, donde se hallaba el alcalde mayor en aquel momento, para pedirle un traslado del documento al respecto. Además un peón viajó a Granada para llevar "vn testimonio de apelaçión sobre quel sennor alcalde no quiso cunplir la executoria que esta villa tiene para aprovecharse de los términos de Chinchilla y sobre que descaminaron a Benito López, veçino

${ }^{95}$ Ibídem. Sesión del 6-VI-1555. Fols. 134ํo-135roํ. 
desta villa, contra la dicha executoria; e porque traýa vna cherrionada de madera" 96.

La disconformidad entre ambos municipios continuó a lo largo de todo el siglo, y aún en el siguiente (Córcoles, 2008, p. 374).

\subsubsection{Con La Gineta}

El conflicto con este pueblo, tras su emancipación de Albacete, estuvo ocasionado principalmente por lo relativo al pago de impuestos, especialmente la alcabala, que entregaban conjuntamente a la Corona; así como el aprovechamiento común de sus respectivas circunscripciones y jurisdicción de los nuevos términos.

En junio de 1554 el rey envió una provisión al gobernador del Marquesado, ordenándole sacar traslado documental de ciertas escrituras, arrendamientos y traspasos que los arrendadores ${ }^{97}$ de la alcabala del viento hacían a algunos vecinos de La Gineta, así como los encabezamientos que se le dieron a la nueva villa de las rentas y alcabalas reales; también las ordenanzas relativas a ganados y guardas de términos (Carrilero, 2000, pp. 430-431). El hecho de que las dos poblaciones pagaran juntas las alcabalas y servicio, daría lugar a enfrentamientos continuos.

En ese momento la disputa está en su fase inicial y son numerosas las quejas de la nombrada nueva villa, acumulándose denuncias por muchos y diferentes motivos. Además, Albacete está tratando varios litigios a un tiempo con otras poblaciones y también con personas particulares. En enero de 1555 el ayuntamiento solicita el envío de un peón a la Corte para comunicar a su procurador que La Gineta arrendaba la "dehesa de boyalaje", en perjuicio de los albaceteños, y que consiga una provisión real que lo desautorice. Para ello, era necesario sacar y remitir, como justificante, el privilegio de Alfonso de Aragón, por el que Albacete se segregó de Chinchilla en 1375, además de la sentencia y declaración del obispo don Pablo, con la mojonera que se hizo y una relación de "todas las visitas questán fechas en las mojoneras desta villa por las justiçias maiores" ${ }^{\prime 98}$.

También, al mismo tiempo, y relativo al pago de alcabalas, se mandarían los señalados arrendamientos y condiciones que los alcabaleros del viento hacían a los vecinos de La Gineta, y que había pedido el rey, así como las obligaciones que estos últimos tenían de pre-

\footnotetext{
${ }^{96}$ A.H.P. de Albacete. Secc. Municipios. Caja 4578. Libro 228. Cuentas de propios 1552-1564. Cuenta del 29-IX-1559 a 29-IX-1560.

${ }^{97}$ Sobre los arrendadores de rentas reales véase (González, 2016).

${ }^{98}$ A.H.P. de Albacete. Sec. Municipios. Caja 4507. Actas capitulares 1552-1562. Sesión del 4-I-1555. Fols. 119vo-120rํ․
} 
sentar los dineros del censo y poderes que dieron para hacerse villa ${ }^{99}$.

El agobio y los gastos que esta disputa originaba al concejo albacetense eran crecientes, por cuanto en junio del mismo año 1555, se recibió licencia del emperador Carlos V para repartir 50.000 maravedís entre sus vecinos, con tal de atender los costes del pleito que mantenía con La Gineta en el Consejo Real, en razón de los términos y sobre la escribanía y correduría de la nueva villa (Carrilero, 2000, pp. 435-436).

En lo que toca a términos y jurisdicción, en las cuentas de propios del concejo son muchas las referencias a pagos efectuados para tal menester. En las de 1554-1555 ya se hace mención de que el pleito está iniciado, pues el albaceteño Nicolás Moreno se presentó en La Gineta a requerir a sus alcaldes y regidores "con vna conpulsoria e manda de los sennores del Consejo de Su Magestat, ...para que pareçiesen a ver corregir çiertas escrituras y avtos, para los enviar a la Corte". También, al solicitador Bartolomé Sánchez se le libraron gastos y honorarios "que se le rrestan debiendo del tiempo que se oqupó en Corte de Su Magestat en la soliçitud de los pleytos questa villa trata con la villa de La Gineta sobre la jurisidiçión, y en otros pleytos" ${ }^{\prime 100}$.

Después, y por lo mismo, se enviaría como solicitador al bachiller Alarcón, interrumpiéndose su llegada a Valladolid, "porque esta villa tubo notiçia que de presente no abía para qué yr porque no heran llegadas ni entregadas las probanças de tachas, e le mandaron bolber della del camino"' $^{\prime 2}$. Aunque luego retomaría el encargo, pues se le hizo libranza de pago por ello y también, en las cuentas siguientes, se le finiquitó por su trabajo ${ }^{102}$. En las de 1557-1558 se le libró cierta cantidad por igualmente desplazarse a la Corte "a entender en los pleytos questa villa trata en ella con la villa de La Gineta y otros pueblos, sobre el aprovechamiento de términos, para parte de pago de su salario y de los derechos que a de pagar". Una vez allí, siguió recibiendo apoyo económico por el mismo asunto $^{103}$. En las cuentas siguientes se aprecia la liquidación de su trabajo en algo más de veintiocho mil maravedís ${ }^{104}$.

Alternando con la función puntual del bachiller Alarcón, hemos visto que el regidor Francisco de Villena actuaría como tal solicitador al respecto ${ }^{105}$ y los problemas de su gestión.

\footnotetext{
${ }^{99}$ Ibídem.

${ }^{100}$ A.H.P. de Albacete. Secc. Municipios. Caja 4578. Libro 228. Cuentas de propios 1552-1564. Cuenta del 29-IX-1554 a 29-IX-1555.

${ }^{101}$ Ibídem.

102 Ibídem. Cuenta del 29-IX-1555 a 29-IX-1556.

${ }^{103}$ Ibídem. Cuenta del 29-IX-1557 a 29-IX-1558.

${ }^{104}$ Ibídem. Cuenta del 29-IX-1558 a 29-IX-1559.

${ }^{105}$ Ibídem. Cuenta del 29-IX-1555 a 29-IX-1556 y cuenta del 29-IX-1556 a 29-IX-1557.
} 
El procurador del concejo, Miguel Sánchez Melero, sería el encargado, junto con el receptor real, de realizar las tachas correspondientes en el pleito, ya que "andubo fuera de esta villa con Álbaro de Torres, rreçebtor, haçiendo las probanças de abonos y tachas sobre lo de La Gineta"106.

También, al vecino Gregorio Martínez se le libraron seis reales, "los quales son de hazer los ynterrogatorios para las probanças de las tachas en el pleyto de La Gineta"107. La documentación extraída, igualmente fue motivo de gastos, encargándose de ella los escribanos de la villa. Uno de ellos, Francisco de Villena ${ }^{108}$, recibió gratificación por "çiento y sesenta hojas de escrituras, que sacó por probisión rreal de Su Magestat", relativas a los privilegios de la villa y otras escrituras de amojonamiento de términos, para enviarlas al Consejo Real, en relación con la causa. Además, sacaría otras "perteneçientes al derecho desta villa en el pleyto que trata con la villa de La Gineta, en que son eleçiones y liçençias de tierras llecas y solares, vna capitulaçión entre esta villa y La Jineta, e çierta sentençia e notificaçiones, e otros çiertos avtos" ${ }^{\prime 109}$.

Otro escribano, Miguel Sánchez de Castillo, se ejercitó un día en ir a Chinchilla a sacar un traslado de la cédula que, sobre el enhestar de mojones, le dio La Gineta ${ }^{110}$. Además se le libraron "tres ducados, que se le dan porque lleve a la Corte çiertas escripturas y la pintura de los términos desta villa, para lo presentar en el pleyto quésta allá trata con la villa de La Gineta, sobre el término y juridizión que pide". Y catorce reales por dos días que se ocupó en trasladarse a la vecina ciudad a requerir con una provisión real "y saber la pintura y rrelaçión de la mojonera" al respecto. Después se le entregarían algo más de once mil quinientos maravedís de treinta días que empleó en ir a la Corte para tratar más asuntos del litigio. También se ordenaron libramientos a otros vecinos que hicieron de mensajeros, llevaron recados o fueron a citar a La Gineta para todos los negocios relativos al caso ${ }^{111}$.

Pero el asunto principal del enfrentamiento era el de la "dehesa de boyalaje" que, aunque parece ser que era de aprovechamiento común para ambas villas, los de Albacete la consideraban de su uso exclusivo,

\footnotetext{
${ }^{106}$ Ibídem. Cuenta del 29-IX-1554 a 29-IX-1555.

${ }^{107}$ Ibídem.

${ }^{108}$ Con este mismo nombre, hemos visto que aparece un regidor en 1556. Con fecha anterior está ejerciendo de escribano. No sabemos si es la misma persona o son dos diferentes.

${ }^{109}$ A.H.P. de Albacete. Secc. Municipios. Caja 4578. Libro 228. Cuentas de propios 1552-1564. Cuenta del 29-IX-1554 a 29-IX-1555.

${ }^{110}$ Ibídem. Cuenta del 29-IX-1555 a 29-IX-1556.

${ }^{111}$ Ibídem. Cuenta del 29-IX-1560 a 29-IX-1561.
} 
y los de La Gineta se tomaban la libertad de arrendarla amparándose en derechos de antaño. Los antecedentes de la propiedad habría que buscarlos en la sentencia arbitraria de 1489 entre ambas poblaciones, en la que los jueces fallaron a favor del vecino lugar (Carrilero, 1983, p. 153). Sin embargo, en febrero de 1555 , al tiempo que se hace constar que también hay pleito sobre la horca y ganancia de tercias, los oficiales albaceteños dan noticia de que se había traído una provisión real "para que la villa de La Gineta no arryende la dehesa". Por lo que se envía al escribano Juan Berruga "a notificalle la provisión a el conçejo de La Gineta y a los arrendadores de la dehesa y pastores questán en ella"12.

En las cuentas de propios encontramos referencias al respecto. El escribano chinchillano, Ginés Gómez, en nombre del concejo albaceteño, se dirigió a la otra parte para hacer un auto de suplicación sobre esa tierra de pasto, "porque la arreildaban"113. Por ir a Valladolid a comunicar esa situación, el vecino Juan Perlado recibiría,

ocho ducados, que se le dan porque fue a la Corte de Su Magestat a llebar çiertos testimonios sobre que La Guineta (sic) arrendaba la dehesa boalaje questá en término desta villa, y otros despachos. Los quales se le dan los çinco ducados que se conçertó con él por el camino, y lo demás de diez y siete días questubo detenido, esperando los despachos, a dos rreales cada vn día. Y truxo carta de hello de Tristán Calbete, proqurador en ella, porque así se asentó con el dicho Perlado ${ }^{114}$.

Además, se dieron veinte reales a Alvar Alarcón, de los días que se ocupó en ir a la villa vecina a requerirle con esas provisiones reales, "para que no vsase del arrendamiento que tenía fecho". También el bachiller Pedro Alarcón, recibió cierto libramiento por lo mismo ${ }^{115}$.

No obstante, parece ser que la nueva villa tenía licencia real para poder vender ese coto. El procurador Miguel Sánchez fue remunerado porque anduvo durante tres días visitando los términos con el licenciado Ibieta, alcalde mayor del Marquesado, y otro día que fue al cercano lugar con Ginés Gómez, escribano vecino de Chinchilla "a suplicar de la liçençia e probisión que Su Magestat dio a La Gineta para bender la dehesa"116.

112 A.H.P. de Albacete. Sec. Municipios. Caja 4507. Actas capitulares 1552-1562. Sesión del 5-II-1555. Fols. 121ro-121o․

${ }^{113}$ Ibídem. Caja 4578. Libro 228. Cuentas de propios 1552-1564. Cuenta del 29IX-1554 a 29-IX-1555.

${ }^{114}$ Ibídem. Cuenta del 29-IX-1554 a 29-IX-1555.

115 Ibídem.

116 Ibídem. 
En cuanto a los problemas referidos a la jurisdicción, los enfrentamientos eran más directos con el vecino pueblo. Todo estaba relacionado con la horca y las varas de justicia, símbolos de jurisdicción e independencia de cada lugar, por lo que cualquier intromisión en ese aspecto incitaba a una acción inmediata e incluso violenta. En las cuentas de propios de 1554-1555 se dieron al procurador Miguel Sánchez 18 reales porque fue a Chinchilla a requerir al escribano, para que sacase de los archivos "çiertas escrituras para presentar en el pleyto de La Gineta, que derribaron la horca y entraron en el término con baras". Consideraba el pueblo de al lado que la horca estaba colocada en su término, la derribaron y colocaron otra en el de Albacete que, recíprocamente, sería a su vez destruida por orden de su concejo. Éste libró diez reales al teniente de alguacil, Pascual López, y a otros tres hombres que llevó con él, "para derribar la horca questava puesta en los términos desta villa, e para pagar la bestia que llevaron"117. También el vecino Juan de Villaescusa prestó un día un par de mulas y un carro para ir "a prender çiertos veçinos de La Gineta que avían puesto vna horca en el término desta villa, e a llevar la gente". Y el escribano chinchillano Ginés Gómez vino a Albacete "a haçer vna informaçión contra los veçinos de la villa de La Gineta, porque sale la justiçia con vara al término desta villa"118. En junio de 1556, el ayuntamiento señalaba esta última circunstancia.

[...] Que la justiçia de la villa de La Gineta salen con varas e vsan de juridiçión en término desta villa (de Albacete) e con gente [e] alboroto. E ay cabsas prinçipiadas sobresto. E para que todo esto se acalle e siga como conviene al derecho desta villa, lo cometían e cometieron al sennor bachiller Cantos, açesor del conçejo, para que sobrello ordene e provea lo que conviene y mandaron al procurador que lo haga ${ }^{119}$.

En las cuentas de 1557-1558, queda reflejado que el mayordomo del concejo se desplazó a Chinchilla a quejarse ante el alcalde mayor, pues los alcaldes de hermandad "salían de la villa de La Gineta con bara fuera de su jurisdiçión ${ }^{120}$. Se comunicó a ese lugar de la gravedad de su intromisión ${ }^{121}$, e incluso el alguacil mayor del Marquesado, Agustín

\footnotetext{
${ }^{117}$ Ibídem.

${ }^{118}$ Ibídem. Cuenta del 29-IX-1555 a 29-IX-1556.

119 A.H.P. de Albacete. Sec. Municipios. Caja 4507. Actas capitulares 1552-1562. Sesión del 29-VI-1556. Fol.183ro.

${ }^{120}$ Ibídem. Caja 4578. Libro 228. Cuentas de propios 1552-1564. Cuenta del 29IX-1557 a 29-IX-1558.

${ }^{121}$ Ibídem. Cuenta del 29-IX-1558 a 29-IX-1559.
} 
Ramírez, se presentaría a prender al alcalde de hermandad y a sus cuadrilleros, porque entraron en la circunscripción albaceteña "y se llevaron presos vnos pastores a la dicha villa de La Gineta"122.

Al final del verano de 1559, el ayuntamiento de Albacete había dado poder a Benito de Molina y a Antón Sánchez para vigilasen el término y prendiesen a cualquier vecino de la otra población que accediere a él "con varas de justiçia e con ganados e faser otros dannos"123. Un año después, aún se seguían cometiendo intromisiones.
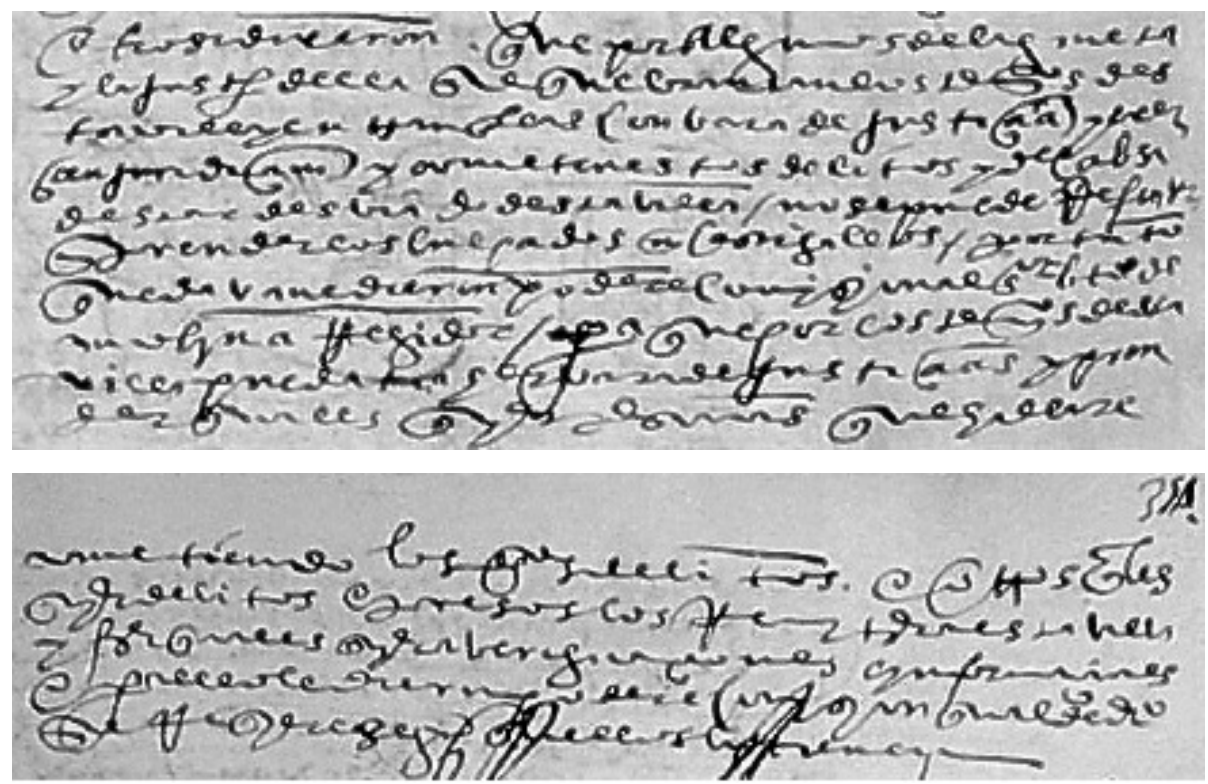

Fragmentos originales correspondientes a la transcripción siguiente. (Fols. 353vo-354rํㅜ).

Otrosí, dixeron que por algunos de La Gineta, y la justiçia della, se quebrantan los términos desta villa y entran en ellas con vara de justiçia i creçen juridiçión y cometen estos delitos. Y, de cabsa destar desviado desta villa, no se puede defender ni prender los culpados ni castigallos. Por tanto que davan e dieron poder e comisión al sennor Benito de Molina, rregidor, para que por los términos desta villa

${ }^{122}$ Ibídem. Cuenta del 29-IX-1559 a 29-IX-1560.

${ }_{123}$ A.H.P. de Albacete. Sec. Municipios. Caja 4507. Actas capitulares 1552-1562. Sesión del 30-IX-1559. Fols. 313ํo-314ro . 
pueda traher vara de justiçias y prender qualesquier personas que hallase cometiendo los dichos delitos e otros qualesquier delitos. E, presos, los rremitir a esta villa y faser qualesquier averiguaçiones e informaçiones. E para ello le dieron poder e comisión qual de derecho se rrequiere, segund quellos lo tienen ${ }^{124}$.

\section{CON HELLÍN}

El conflicto en este caso vendría por ciertas dehesas que se hicieron en terrenos de aprovechamiento común. Por ello, se presentó demanda ante el alcalde mayor del Marquesado de Villena.

Ya en 1494 los Reyes Católicos facultaban al entonces gobernador del Marquesado para que hiciese justicia sobre la queja de unos vecinos de Albacete que, teniendo comunidad de términos con Hellín, este lugar había acotado terrenos para hacer una redonda, usurpando así en beneficio propio, mucha parte del término comunitario; "e que si entran en ella los ganados de la dicha villa de Albaçete, los prendan" (Carrilero, 1983, pp. 178-179). En 1528 el emperador Carlos V y su madre prohibían a los concejos de Chinchilla, Almansa, Hellín, Tobarra, Jorquera, Carcelén y Montealegre que hiciesen nuevos acotamientos en los términos comunes con la villa de Albacete (Carrilero, 1983, pp. 355-356).

En las cuentas de propios de 1557-1558, consta el libramiento a un mensajero por trasladarse a Hellín y Almansa a notificar un mandamiento del alcalde mayor, doctor del Águila, para que "pareçiesen a ver sacar e corregir çiertas escripturas sobre dehesas" que Albacete pedía "para guarda de su derecho"125. El concejo albaceteño instaría a sus vecinos a que ocupasen esos terrenos con sus ganados para, de esta forma, provocar intencionadamente el pleito.

[...] Los dichos sennores dixeron que las villas de Hellín e Almansa an fecho çiertas dehesas y ensanchos en sus términos e perjuizio desta villa; que avisan a los vezinos desta villa que metan los dichos ganados en los dichos ensanchos e dehesas nuebas e se aprobechen dellos; que sy los prendaren, el conçejo desta villa los librará e hará bolver sus prendas que les tomaren, e los sacarán a paz e a salbo ${ }^{126}$.

La fórmula haría efecto, pues en octubre de 1559 se da noticia de que al vecino Francisco Jiménez le habían tomado diez ovejas y una

\footnotetext{
${ }^{124}$ Ibídem. Sesión del 7-X-1560. Fols. 353vo-354ro․ 125 A.H.P. de Albacete. Secc. Municipios. Caja 4578. Libro 228. Cuentas de propios 1552-1564. Cuenta del 29-IX-1557 a 29-IX-1558. 126 Ibídem. Caja 4507. Actas capitulares 1552-1562. Sesión del 14-I-1559. Fol. $297 \mathrm{v}^{\mathrm{o}}$.
} 
burra en el Rincón del Moro, en Hellín, "y es cosa muy ynportante que se deshaga" la tal dehesa. Por ello se pedía al afectado Jiménez que diese poder para contradecir y solicitar la devolución de lo que le fue prendado, siguiéndose el proceso a costa del concejo de Albacete ${ }^{127}$.

E para que más con brebedad se haga, nonbran porque vayan al alcalde mayor a negoçiar con él, a los magníficos sennores el bachiller Alarcón, alcalde hordinario, e a Pedro Carrasco, alférez. E para ello les asinaron de salario vn escudo (unos 10 reales) a cada vno por cada vn día por ser cosa tan ynportante el negoçio a esta villa ${ }^{128}$.

Las cuentas de 1558-1559 muestran el pago de cierta cantidad al procurador Miguel Sánchez, por ir a Cuenca a sacar los procesos que se trataban con Hellín y Almansa, según el dictamen del juez de comisión bachiller de la Torre ${ }^{129}$. En las de 1559-1560 vemos que el propio mayordomo del concejo, Juan del Cobo, como apoderado del dicho Francisco Jiménez, había ido a requerir a la parte contraria. Respondiendo a lo alegado por esta última, también se desplazó hasta Chinchilla para traer los despachos correspondientes. Por su parte, el alcalde mayor del Marquesado, licenciado Estrada, emitiría un mandamiento "para que deshagan la dehesa del Rrincón del Moro". La orden fue notificada a la villa de Hellín, citándola para los autos del proceso y por si "se quería hallar presente a ver sacar la sentençia que dio el bachiller de la Torre, juez de comisión sobre la dicha dehesa"130.

Es evidente pues que, en estos años 1559-1560, es cuando este pleito está en su punto álgido, ya que entonces se ocasionan el mayor número de gastos y libramientos al respecto. Además de los ya señalados, a finales de 1559, el mayordomo Cobo declara haber realizado otros pagos: Por sacar un mandamiento del licenciado Estrada, "para que el conçejo de la villa de Hellín bolviese las rreses que avía tomado a Françisco Ximenes de Villanueva, en el Rrincón del Moro". Al escribano Bartolomé de Munera, de dos peticiones que redactó para presentar en el proceso y de un escrito e interrogatorio sobre lo mismo. Al alcalde mayor y su escribano, de derechos. Al señalado Munera, por un escrito para concluir en la causa. El propio mayordomo sería compensado con 2.278 maravedís en la liquidación de cuentas de ese período, por haber participado en la gestión ${ }^{131}$.

\footnotetext{
${ }^{127}$ Ibídem. Sesión del 8-X-1559. Fol. 315ํo. ${ }^{128}$ Ibídem. Sesión del 4-XII-1559. Fols. 318vo-319ro․ ${ }^{129}$ A.H.P. de Albacete. Secc. Municipios. Caja 4578. Libro 228. Cuentas de propios 1552-1564. Cuenta del 29-IX-1558 a 29-IX-1559.

${ }^{130}$ Ibídem. Cuenta del 29-IX-1559 a 29-IX-1560.

${ }^{131}$ Ibídem.
} 
Otros pagos que se hicieron en las mismas fechas fueron: A Lorenzo de Avilés, escribano de Chinchilla, por derechos del proceso. Al procurador de la misma ciudad, porque trajo cargo de presentar los testigos. Al escribano y procurador albaceteño Garci Hernández de Córdoba "de vn día que se ocupó en yr a la çibdad de Chinchilla a traer el traslado del rreplicato que hizo la villa de Hellín". A Miguel Sánchez del Castillo, escribano de Albacete, por ir a Sax a buscar al alcalde mayor, licenciado Estrada, para que decretase y concluyese el pleito; y por ir a Chinchilla a requerir al mismo alcalde para que la otra parte devolviese las prendas tomadas, y sacar mandamiento para notificar la sentencia a los otros contendientes ${ }^{132}$.

A finales de 1560 el asunto parecía tocar a su fin, según señala el expresado mayordomo, que había hecho un libramiento por sacar un traslado del veredicto ${ }^{133}$. Aunque en diciembre de 1561, los oficiales del concejo de Albacete "mandaron que se vaia a acabar de feneçer el pleito que se trata con Hellín sobre la nueba dehesa del Rrincón del Moro"134.

La causa llegó a la Corte, que dictaminó a favor de la villa de Hellín, para que disfrutara de ese cercado durante un tiempo determinado. A comienzos del siglo XVII, en 1614, los dos lugares tornarían a pleitear, porque los hellinenses querían volver a acotar en su favor el dicho Rincón del Moro. El concejo albacetense expresaba al respecto "que ha venydo a notizia deste ayuntamyento cómo la dehesa del Rrincón del Moro, térmyno de Hellín, a cumplido ya con el tiempo que Su Magestad le hizo merzed a la dicha villa, y que se trata de bolberla a amojonar y a hazer dehesa" (Córcoles, 2008, pp. 391-392).

\section{CON LA RODA}

Albacete no tenía comunidad de términos con La Roda y Alcaraz, aunque con ésta última hubo ciertas intenciones, por parte real, de que la hubiera. En las cuentas de propios de 1556-1557 se dieron a un vecino cuatro reales por ir a mostrar una carta a los oficiales del concejo, que estaban en sus heredades, "quescrivió la villa de San Clemeinte para si querían pedir a Su Magestat hiçiese los términos con la çiudad de Alcaraz"135. En junio 1557 el ayuntamiento se ocupó del asunto. Aunque no queda

\footnotetext{
${ }^{132}$ Ibídem.

${ }^{133}$ Ibídem.

${ }^{134}$ A.H.P. de Albacete. Sec. Municipios. Caja 4507. Actas capitulares 1552-1562. Sesión del 8-XII-1561. Fol. 391o․

${ }^{135}$ A.H.P. de Albacete. Secc. Municipios. Caja 4578. Libro 228. Cuentas de propios 1552-1564. Cuenta del 29-IX-1556 a 29-IX-1557.
} 
expresada su decisión en el acta, se informa de cómo el rey "hará pasto común los términos de la çibdad de Alcaraz con los pueblos comarcanos por alguna cantidad de dinero". Para ello se celebrarían juntas el último día de Pascua. Albacete decidió enviar a San Clemente al alcalde ordinario Bartolomé Sánchez, con carta credencial de la villa e instrucción de lo que habría de tratar ${ }^{136}$.

Dos años después, a finales de julio de 1559 se recibe la noticia de que en los términos de la villa entraban ganados forasteros, especialmente por la parte que está hacia La Roda y Alcaraz. Al ser zonas apartadas de la población, "y los cavalleros de sierra son pobres y no tienen cavallos para lo poder vysitar", no se podía evitar la intromisión. Para poner remedio, se dio poder al vecino Francisco del Castillo, "que tiene heredamiento a las partes del dicho término, para que pueda poner en él la guarda que convenga", llevando vara de justicia y tomando prendas a quienes invadiesen esos terrenos ${ }^{137}$.

Los ganados de La Roda que entraban en término albaceteño eran quintados, es decir, tomadas parte de sus cabezas como prenda y pago, por ser tierras no comunitarias. En abril de 1560 el ayuntamiento declara haber tomado ciertas reses a unos vecinos de aquel lugar, concretamente "se an quintado vna manada de ganado de Antón López el viejo i otra de Antón López el moço", los cuales fueron a quejarse ante el gobernador, entablándose por ello el consiguiente litigio. ${ }^{138}$. En las cuentas de propios también queda constancia del hecho, pues se libraron 36 reales al vecino Juan Martínez Serrano, de dieciocho días que se ocupó "en guardar çiento e quarenta e dos cabeças de ganado del quinto questa villa hizo en los términos della" al citado Antón López ${ }^{139}$.

La causa llegó ante el gobernador del Marquesado de Villena. Se observan varios libramientos al respecto en las cuentas de 15591560, como al abogado bachiller Avilés, al escribano Francisco Simón y al procurador Miguel López, vecinos de San Clemente, por su trabajo en el proceso que se seguía "contra Antón López, veçino de La Rroda sobre el quinto". El escribano Garci Hernández de Córdoba, como procurador del concejo de Albacete, recibió también cierta cantidad por ir a las villas de San Clemente y La Roda a entender sobre lo mismo. Igualmente el amanuense Bartolomé de Munera fue

${ }^{136}$ A.H.P. de Albacete. Secc. Municipios. Caja 4507. Actas capitulares 1552-1562. Sesión del 5-VI-1557. Fol. 220roo. 
gratificado por "tres petiçiones que escribió" para el ayuntamiento rodense $\mathrm{e}^{140}$.

\section{SOBRE EL REGISTRO DE GANADOS}

Otro litigio de la villa de Albacete, y el de otras del Marquesado, fue el referido a la franqueza que manifestaba tener sobre el registrar los ganados en los puertos secos, dentro de las doce leguas desde la raya de Valencia y Aragón, alegando que la tenían desde tiempo inmemorial.

Ya en marzo de 1514, la reina doña Juana había enviado una provisión a su recaudador Rodrigo de Valderrama, en la que se aclaraba que los vecinos del Obispado de Cartagena que estuviesen a diez leguas del mojón de Aragón, estaban obligados cada año a asentar ante él los ganados mayores y menores, so pena de perderlos. Pero los albaceteños entendían lo contrario, creían que eran francos de hacerlo quienes estaban a esa distancia. Por todo ello, la soberana ordenaba ahora que se hiciesen los registros sólo de cien cabezas arriba (Carrilero, 2002, pp. 201-207). No obstante, como veremos en el tiempo que tratamos, serían doce las leguas que marcaría el expresado mojón. Las controversias sobre el asunto continuarían bajo el mandato de Carlos V (Carrilero, 1983, p. 382; 2000, pp. 170-173, 202-207).

A mediados de siglo las disputas por este asunto aún estaban presentes. En agosto de 1555, el licenciado Juan Ponce de León, juez de comisión del rey y de sacas y cosas vedadas a los reinos de Aragón y Valencia, estaba en la villa manchega procediendo contra todos los que no tenían su ganado registrado. Como el concejo alegaba que nunca se había acostumbrado a ello, mandó a su procurador que, bajo asesoramiento del bachiller Cantos, pidiese al juez testimonio sobre el caso, y después se enviase a la Corte ${ }^{141}$. En ayuntamientos posteriores se volvería a insistir en presentar ante la realeza la queja pertinente sobre los agravios cometidos por Ponce de León, e incluso la conveniencia de que "se escriva a Chinchilla para que se junte con esta villa a defender el pleito del registrar los ganados ${ }^{\prime 142}$.

$\mathrm{Al}$ ser el asunto común en otros pueblos, a primeros de octubre se acuerda hacer coalición con ellos.

Otrosí, dixeron los dichos sennores alcaldes e rregidores que se a platicado que se junten los pueblos deste obispado de Cartagena para tratar de los agravios que haze el liçençiado Juan Ponçe de

\footnotetext{
${ }^{140}$ Ibídem.

${ }^{141}$ A.H.P. de Albacete. Sec. Municipios. Caja 4507. Actas capitulares 1552-1562. Sesión del 30-VIII-1555. Fol. 146ro .

${ }^{142}$ Ibídem. Sesión del 14-IX-1555. Fols. 149ro-150roo.
} 
León, juez de comisión de Su Magestat. Que se escriva a la çibdad de Chinchilla para que aperçiba a los demás pueblos, e que vaya el sennor Françisco de Villena, rregidor, a tratar como se a de faser la dicha junta y lugar e día ${ }^{143}$.

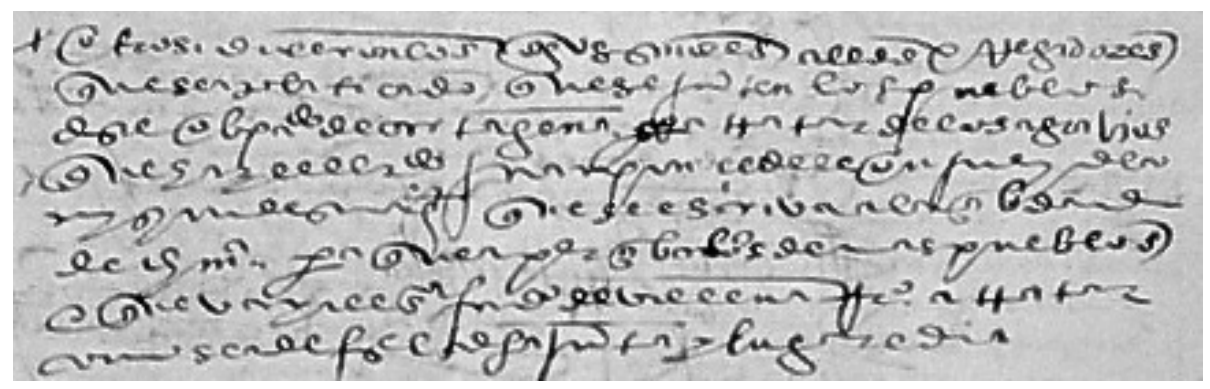

Fragmento original del texto anterior (Fol. 159rº).

El 26 de ese mes, ya se ha establecido contacto con otros lugares para hacer una queja conjunta. Se acuerda hacer una reunión en Chinchilla, a la que por parte de Albacete irían el alcalde ordinario bachiller Cantos y el regidor Juan de Alcañavate de la Cueva, con un ducado de salario diario cada uno, "e que para el lunes primero viniente estén en la çibdad de Chinchilla a faser la dicha junta"144. Días después se hace constar cómo se había llegado a un acuerdo con la vecina ciudad, aunque no con los demás pueblos. Conciertan ambos lugares en enviar a la Corte a un solicitador vecino de Chinchilla, con honorarios de ocho reales diarios pagados por Albacete y dos ducados más que daría la parte chinchillana ${ }^{145}$. Se establecía pues un pacto para tratar un asunto que perjudicaba a ambos lugares. En ese compromiso intervendría también el alcalde mayor, tal y como puede observarse en un libramiento hecho al regidor Benito López de Belmonte por ir "a llamar al sennor alcalde maior e a tratar con la çibdad de Chinchilla que se hiçiese justiçia sobre los agravios que hizo Juan Ponçe, juez de cosas vedadas ${ }^{\prime 146}$.

Igualmente, el procurador del concejo, Miguel Sánchez, se había desplazado a Villena a apelar directamente ante ese juez por la sentencia por él dada contra los vecinos y ganaderos. Con ese apoderado había viajado también el escribano Juan Berruga, que cobraría por ir después a Hellín, a notificar al propio Ponce de León las provisiones

${ }^{143}$ Ibídem. Sesión del 10-X-1555. Fol. 159ro․

${ }^{144}$ Ibídem. Sesión del 26-X-1555. Fols. 161ro-162ro․

${ }^{145}$ Ibídem. Sesión del 3-XI-1555. Fols. 162vo-163ํㅡ.

${ }^{146}$ A.H.P. de Albacete. Secc. Municipios. Caja 4578. Libro 228. Cuentas de propios 1552-1564. Cuenta del 29-IX-1555 a 29-IX-1556. 
reales en las que Albacete justificaba su queja " $y$, quiriéndoselas notificar, el dicho presó i lo tubo tres días preso"147.

A primeros de diciembre, concejo y particulares enviaron a la Corte al regidor Juan de Alcañavate, con un ducado diario de salario, además de los dos que recibía de los ganaderos agraviados, pues habían sido condenados más de ciento veinte vecinos, por no registrar los rebaños, en una cuantía total superior a cuatro mil ducados. Esta pena había sido ejecutada, a pesar de haber apelado la villa y tener pleito pendiente ante los contadores mayores, "e así mismo dize el dicho sennor juez que a de faser maiores condenaçiones y no se sabe de qué"148. El regidor iría a cumplir su cometido y, en las cuentas de propios de 1555-1556, queda reflejado que se le enviaron dineros para pagar los honorarios de los negocios y sentencias dadas por el licenciado Ponce ${ }^{149}$.

En este estado del asunto, el emperador Carlos V enviaría una provisión, fechada el 24 de diciembre en Valladolid, exigiéndole al juez que, tanto él como su escribano, cumpliesen las normas de procedimiento, sin excederse en los procesos. Se contiene también en la carta cómo el procurador Tristán Calvete se había dirigido igualmente al mismo Ponce de León, quejándose de su proceder con la villa de Albacete:

[...] eçediendo de vuestra comisión, y por molestar a los vezinos de la dicha villa, avéys puesto diez y seys alguaziles y casi otros tantos honbres sin auer dello neçesidad, y solamente a hefeto de los aprouechar dándoles grandes salarios. Y que, non enbargante que los vezinos de la dicha villa, contra quien auéys proçedido e proçedéys sobrel dicho negoçio, muestran e prueban auer bendido sus ganados a personas conosçidas y abonadas, naturales destos rreynos, proçedéys contra ellos como si vbiesen cometido algún delito, sin enbargo que tenisdes presos y arraygados con fiança a las mesmas personas que auían conprado los dichos ganados.

Por manera que molestáuades a los vnos y a los otros sin auer causa ni rrazón para ello, y sin auer color para poder molestar a los dichos vendedores que mostrauan y prouauan auer bendido los dichos ganados a personas conosçidas y abonadas y naturales destos rreynos.

Y, ansí mismo, porque no se nos pudiese dar notiçia de los agrauios que hazíades, no consentíades que los autos de las execuçiones, y otras cosas que hazíades, quedasen en poder de los escriuanos ante quien pasaban. Antes mandábades que los executores, que teníades diputados para lo susodicho, tomasen e tubiesen en su poder todos los dichos

\footnotetext{
${ }^{147}$ Ibídem.

148 A.H.P. de Albacete. Sec. Municipios. Caja 4507. Actas capitulares 1552-1562. Sesión del 2-XII-1555. Fol. 164vo․

${ }^{149}$ Ibídem. Caja 4578. Libro 228. Cuentas de propios 1552-1564. Cuenta del 29-

IX-1555 a 29-IX-1556.
} 
autos y que no los dexasen en poder de los dichos escriuanos.

$Y$ el escriuano y escriuanos que tenéys lleuan eçesivos salarios, sin guardar en lo llevar dellos las leyes de nuestros rreynos, y no quieren dar carta de pago de lo que rresçiben. Y ansí non se podía aueriguar ni dar quenta ni rrasón alguna, por ser muchos los negoçios que ante uos pasan. De todo lo qual, sus partes heran mui agrauiados e molestados" (Carrilero, 2000, pp. 443-446).

En medio de toda esta preocupación y gestión por parte de la villa, los alcaldes ordinarios de la misma fueron llamados a Murcia por Ponce de León ${ }^{150}$. En enero de 1556, el concejo acepta el mandato de ese juez, que le exigía nombrar depositario para recibir las condenaciones hechas contra los vecinos, "y, en conplimiento dello, nonbraban e nonbraron por depositario de las dichas condenaçiones al sennor Juan de Alcannavate de la Cueva, rregidor, por ser rrico e abonado"151. Se desplazaría a Murcia el procurador Miguel Sánchez, con tal de sacar los procesos de los ganaderos afectados y requerir al juez que aceptase a Alcañavate como tal depositario. Desde la Corte, el bachiller Alarcón, como solicitador, y Tristán Calvete como procurador, gestionaban el asunto enviando cartas y provisiones para que el consistorio requiriese a su vez con ellas ante el propio juez Ponce ${ }^{152}$.

A mediados de abril, el regidor Jorge de Alcañavate expresaba su opinión de lo que estaba ocurriendo al respecto, y que la villa de Albacete estaba exenta de registrar sus ganados por estar situada dentro de las doce leguas del límite con el reino de Valencia, "de tienpo ynmemorial a esta parte i dende la fundaçión desta tierra". Deduciendo que si se cumplía el dictamen del juez, "la gente prinçipal rrica que bibe de alguna grangería de ganados que sirve a Su Magestat en pagar los pechos e derramas que se le rraparten, publican e dizen que se desavezindarán e se irán a vivir a otras partes”. Por lo que insta al concejo a seguir el pleito contra la sentencia, revelando además la deslealtad de algunos vecinos que, contraviniendo el derecho de la villa, "rregistran sus ganados en çiertas casas o donde les pareçe, secretamente". Este Alcañavate, como regidor, "y en nonbre de lo pobres i güérfanos e bibdas y demás rrepública de la dicha villa", pedía que fuesen desavecindadas esas personas que actuaban a espaldas del derecho del pueblo. Además requería al alcalde mayor, licenciado Sahagún, que estaba presente en el ayuntamiento, "castigue a los dichos particulares que así ovieren rre-

${ }^{150}$ A.H.P. de Albacete. Sec. Municipios. Caja 4507. Actas capitulares 1552-1562. Sesión del 17-I-1556. Fols. 167ro-167ํㅜ․

${ }^{151}$ Ibídem. Sesión del 25-I-1556. Fol. 167Vํㅡ.

${ }^{152}$ A.H.P. de Albacete. Secc. Municipios. Caja 4578. Libro 228. Cuentas de propios 1552-1564. Cuenta del 29-IX-1555 a 29-IX-1556. 
gistrado y les mande pareçer ante sí e le aclaren por qué cabsa an fecho el dicho registro" 153 .

En octubre, se presentó en la villa el licenciado Miguel Marañón como nuevo juez de las cosas vedadas, para hacer juicio de residencia a su antecesor Ponce de León, y tomar informes sobre su buena o mala gestión. El ayuntamiento da cuenta de su malestar por los muchos agravios y molestias que el saliente había hecho a sus vecinos, "que los destruyó e les costó más de ocho mill ducados y los desaforava y lleva a Murçia i a otras partes con gastos e salarios eçesyvos". Por ello deseaban que él y sus oficiales fuesen castigados para ejemplo de los jueces vinientes, "porque otros no se atrevan a faser los semejantes agravios". Se acuerda que se pregone en la plaza pública, para que los perjudicados puedan testimoniar lo hecho por el antecesor. También está presente el alcalde mayor Sahagún, quien hace constar que esa investigación debe ser costeada por los propios agraviados, a excepción de los pobres. Y que si se demuestra que el juez anterior hizo ofensa a la villa y a sus vecinos, que se proveerá sobre ello en consecuencia. El concejo tomó el asunto como propio y no acepta el parecer de Sahagún de que sean los vecinos perjudicados quienes lo sufraguen. Incluso los oficiales asumen ellos mismos el coste, " $y$, en quanto al gasto, ellos lo quieren pagar de sus haziendas e no se gasten de propios del conçejo"154.

Al mes siguiente, en noviembre, queda constancia de la confirmación, por parte real, de la sentencia que en su día dio el referido Ponce de León y se toma parecer al asesor, el licenciado Alarcón (no se debe confundir con el albaceteño bachiller Alarcón), "sy convenía a esta villa salirse de las doze leguas o quedarse dentro". Se acordó en continuar el pleito en grado de apelación y demostrar ahora todo lo contrario: que la villa de Albacete estaba fuera de las doce leguas del reino de Valencia y por tanto no estaba obligada a registrar los ganados, "porquesta villa está fuera de las doze leguas por todas las partes que se quiera medir, conforme a la Lei de la Partida". Para demostrar esto, era necesario pedir un receptor a la Corte con tal de hacer la probanza y la correspondiente medida, así como un juez que esté presente a ello ${ }^{155}$. Al dicho licenciado Alarcón, vecino de Jorquera, se le libraron seis ducados por su trabajo de asesor, por seis días que se detuvo en Albacete para "çiertos negoçios tocantes a esta villa sobre los rregistros de los ganados i otras cosas, e si convenía salirse de las doze leguas" ${ }^{\prime 56}$.

${ }^{153}$ A.H.P. de Albacete. Sec. Municipios. Caja 4507. Actas capitulares 1552-1562. Sesión del 15-IV-1556. Fols. 180vo-181ro․

${ }^{154}$ Ibídem. Sesión del 6-X-1556. Fols. 194ro-195ro․

${ }^{155}$ Ibídem. Sesión del 4-XI-1556. Fols. 197roํ-197oo.

${ }^{156}$ A.H.P. de Albacete. Secc. Municipios. Caja 4578. Libro 228. Cuentas de propios 
A pesar de esta nueva actitud del concejo albaceteño de excluirse de las doce leguas, todavía se continuaba tratando sobre los pagos al respecto y, en junio de 1557, el nuevo juez de sacas y cosas vedadas, licenciado Marañón, inició también una serie de pesquisas e informaciones sobre los ganaderos que no tenían registrados sus animales ${ }^{157}$. Al mes siguiente, el ayuntamiento deja constancia de que la sentencia dada por el anterior juez Ponce contra los cabañeros de la villa, les había condenado y llevado muchas costas y salarios. Que se había recurrido y seguido pleito en grado de apelación, dándose nueva sentencia en el Consejo Real, en la que se ordenaba devolver "a los vezinos desta villa los marauedís quel dicho Juan Ponçe condenó". No obstante, Marañón, a pesar de estar el pleito en grado de revista, seguía procediendo contra los cabañeros, habiendo enviado incluso un alguacil y un escribano para que les tomasen declaraciones, " $y$, tomadas, los çite para que vaian a defenderse ante el dicho sennor juez, y para sus costas y salarios hazer que deposite cada cavannero siete u ocho rreales"158.

El ayuntamiento albaceteño envió al escribano Miguel Sánchez del Castillo a la villa de Yecla, donde en aquellos días se encontraba Miguel Marañón, a suplicarle "que no se entremetiese en conosçer del rregistro de los ganados de los veçinos desta villa, porque avía pleito pendiente"159. El mismo Sánchez del Castillo también sería designado para presentarse ante el Consejo Real y pedir que cesasen las molestias del nuevo juez ${ }^{160}$.

Como la villa había decidido ahora salir de la demarcación de las doce leguas con tal de eludir los registros, a finales de 1558 se da noticia de que había venido un receptor para comprobarlo. Se encomendó al procurador del concejo, Miguel Sánchez "que asista en la probança y comiençe a faser luego e pregunte los testigos que conviene presentar en esta villa i en la comarca donde se hallaren"161. Recibiría setenta reales por diez días que estuvo fuera, con el receptor real Francisco de Sobremonte. Éste, a su vez, se ocupó cincuenta y seis días realizando su cometido, atendido por el regidor bachiller Munera ${ }^{162}$.

1552-1564. Cuenta del 29-IX-1555 a 29-IX-1556.

157 Ibídem. Caja 4507. Actas capitulares 1552-1562. Sesión del 5-VI-1557. Fol. $220 r^{0}$.

${ }^{158}$ Ibídem. Sesión del 7-VII-1557. Fol. 221o․

${ }^{159}$ A.H.P. de Albacete. Secc. Municipios. Caja 4578. Libro 228. Cuentas de propios 1552-1564. Cuenta del 29-IX-1556 a 29-IX-1557.

${ }^{160}$ Ibídem. Caja 4507. Actas capitulares 1552-1562. Sesión del 7-VII-1557. Fol. $221 v^{0}$.

${ }^{161}$ Ibídem. Sesión del 7-XII-1558. Fol. 296rº.

${ }^{162}$ A.H.P. de Albacete. Secc. Municipios. Caja 4578. Libro 228. Cuentas de propios 
En cuanto a la ejecución de las medidas del terreno, y para demostrar que Albacete estaba fuera de ese límite, se dieron 122 reales al bachiller Díaz, por ocuparse durante seis días "en yr a medir las leguas que ay dendesta villa a la rraya del rreyno de Valençia, con otras personas que fueron con él a las medir, para presentarlos por testigos en la probança questa villa a fecho sobre estar fuera de las doze leguas". Los acompañantes expresados, eran cuatro vecinos de Carcelén que cobrarían 22,5 reales por ayudar durante cinco días a Munera. También se libraron 50 reales que se gastaron con la gente que el bachiller llevó "para testigos de vellas medir". Y 17,5 reales "que costó vna mula e vn cherryón e vn moço que se ocupó los días en llebar las medidas y la provisión para la gente que iba para el dicho efecto". Igualmente se hizo libramiento al alpargatero Diego del Peral, "de nueve libras e media de cordal de cánnamo hilado que dio al conçejo" para medir las expresadas leguas ${ }^{163}$.

En abril de 1559, todavía continuaba el pleito por las sentencias anteriores. Se da noticia también de que el licenciado Marañón ya no ostentaba el cargo de juez de comisión de las cosas vedadas, y el proceso había salido de la Corte "y se cometieron las cabsas a las justiçias ordinarias deste Marquesado y las rremitió al sennor dotor del Águila, alcalde maior deste Marquesado, y no los a sentençiado"164. Así, ahora el Consejo Real había remitido a la Gobernación del Marquesado de Villena la resolución final sobre el asunto, y el alcalde mayor no sólo no la ejecutaba, sino que seguía perjudicando a los albaceteños, procediendo contra ellos. A pesar de haberse encomendado a dos regidores (Andrés de Cantos y el bachiller Munera) que se ocupasen de llevar a buen término este caso, todavía, a finales de agosto permanecía en el mismo estado. Se volvería a encargar la gestión a dos personas: al anterior Andrés de Cantos y al bachiller Alarcón ${ }^{165}$.

Iniciado el siglo XVII la controversia sobre el registro de ganados continuaba, a pesar de que la villa había conseguido salir del ámbito de las doce leguas, "questa villa le a costado el salir de las doce leguas por pleito en los Consexos de Su Magestat, quatro o çinco mill ducados, y oy antes le sería de daño el aberlo hecho". Pues ahora, en 1624, el rey había ordenado que los ganaderos que estuviesen fuera de las dichas doce leguas debían registrar sus ganados (Córcoles, 2008, pp. 366-370). Antes se les exigía registrar los ganados porque estaban dentro de las doce leguas, y ahora porque estaban fuera.

1552-1564. Cuenta del 29-IX-1558 a 29-IX-1559.

${ }^{163}$ Ibídem.

${ }^{164}$ A.H.P. de Albacete. Sec. Municipios. Caja 4507. Actas capitulares 1552-1562. Sesión del 11-IV-1559. Fol. 300vo.

${ }^{165}$ Ibídem. Sesión del 29-VIII-1559. Fol. 308ro․ 


\section{SOBRE LA HIDALGUÍA DE LOS ALFARO}

Dados los privilegios de que gozaban los hidalgos respecto a la fiscalidad, así como la ocupación de cargos concejiles por su derecho de mitad de oficios ${ }^{166}$, no resulta extraño que muchos vecinos de Albacete tratasen de demostrar esa condición. En este tiempo, el consistorio continuaba el llamado pleito de los Alfaro, que venía existiendo por lo menos desde 1539, en que los hermanos Fernando y Gabriel Alfaro pretendían hidalguía, siendo pecheros como eran (Moreno, 1984, p. 28).

Aunque el litigio ya estaba presente en la Chancillería de Granada desde años anteriores, ahora se libraba cierta cantidad al procurador Miguel Sánchez porque fuese a buscar al receptor real Sancho de Loyola, "para cobrar los beynte ducados que mandó depositar por la rrequisaçión del pleyto de los Alfaros". También serían compensados el propio procurador y el receptor Acuña por hacer las probanzas ${ }^{167}$.

Fue el solicitador Pedro Cebrián quien se ocupó más de lleno por el asunto, como hemos visto. En las cuentas de 1555-1556 se refleja el pago a un peón que trajo desde Granada unas cartas de aquél, "sobre que se veía el pleito de los Alfaros ${ }^{\prime 168}$. Aunque, en marzo de ese año 1556 el concejo instaba a Cebrián a que regresase a Albacete en caso de no estar empezado el pleito ${ }^{169}$, él continuaría con la gestión, desobedeciendo el mandato de la autoridad municipal, solicitando incluso que se le enviase dinero, ya que el "pleito de los Alfaros se verá pasada la Pascua ${ }^{\prime 170}$. En agosto se le da de plazo hasta San Miguel de septiembre para que regrese, "e si no estubiese botado el pleito de los Alfaros el día de San Miguel, se venga e lo dexe con lo questuviere fecho"171. Pero en noviembre aún seguía allí y el proceso estaba en grado de revista y

\footnotetext{
${ }^{166}$ Mitad de oficios.- Distribución por igual de los cargos concejiles entre nobles y gentes del común. En este tiempo los hidalgos albaceteños disponían en el concejo de un alcalde de hermandad, de los dos elegibles anualmente. A partir de la elección de 1576 aparece lo propio también con un alcalde ordinario (Córcoles, 2002, p. 62). ${ }^{167}$ A.H.P. de Albacete. Secc. Municipios. Caja 4578. Libro 228. Cuentas de propios 1552-1564. Cuenta del 29-IX-1554 a 29-IX-1555.

${ }^{168}$ Ibídem. Cuenta del 29-IX-1555 a 29-IX-1556.

${ }^{169}$ A.H.P. de Albacete. Secc. Municipios. Caja 4507. Actas capitulares 1552-1562. Sesión del 18-III-1556. Fol. 173o․

${ }^{170}$ Ibídem. Sesión del 4-IV-1556. Fols. 176ro-177rํ․

${ }^{171}$ Ibídem. Sesión del 22-VIII-1556. Fols. 186ro-186vo․
} 
remitido a otra sala ${ }^{172}$. El consistorio insiste en cómo había requerido la presencia de Cebrián para que explicase la marcha del asunto, "y no lo a querido faser, antes lo a desimulado y agora a escrito a sus merçedes quel dicho pleito se vido e rremitió a otra sala". Se consideraba que su estancia en la ciudad andaluza no era necesaria y sí muy costosa para la villa y sin fruto ni provecho alguno. Por lo que es conminado a que sin dilación regrese y dé cuenta del negocio y de lo que en él tiene hecho para que, visto todo, "se provea para después de Pascua lo que más convenga". Se le revocó el poder que se le tenía dado; " $e$ mandavan $e$ mandaron que no entienda más en el dicho negoçio ni en otro alguno que a esta villa toque, ni gane salario dello", enviándole insistentemente notificación como vimos ${ }^{173}$.

A finales de diciembre ya está presente Cebrián en Albacete para dar cuenta y razón de su gestión, volviendo a remarcar, como ya había indicado, que el pleito estaba en grado de revista, remitido a la sala del licenciado Frías y que no se vería hasta después de Pascua. A pesar de ello, el concejo le exige la entrega de los memoriales y relación del proceso ${ }^{174}$.

No obstante de la obstinación en que el referido solicitador dejase de entender en el asunto, aún lo enviarían otra vez a Granada. En febrero de 1557 se consideró que había dado buena cuenta de su misión, "por donde le pareçe estar bien istruido e informado". El motivo de su retorno estaba en que, con su venida, la villa había quedado allí desamparada y sin representación. La situación era aprovechada por la parte contraria, que "trabaja e procura porque se vea el pleito sin que se halle persona por esta villa presente"175. En septiembre los oficiales apuntaban "que Pedro Çebrián, soliçitador desta villa, a enviado el traslado de las sentençias contra los Alfaros en fabor desta villa"176.

Ya sabemos que los honorarios los recibía Cebrián a través de su padre, Alonso Hernández, el cual había ocupado el cargo anteriormente y también había entendido en el mismo pleito. Igualmente se encargaba de trasladarle a su hijo el dinero y la documentación que en cada momento fuese necesaria ${ }^{177}$. En las cuentas de propios de 1556-1557 se ven reflejados numerosos libramientos, relativos a la causa, por sa-

\footnotetext{
${ }^{172}$ Ibídem. Sesión del 7-XI-1556. Fol. 198ro-186vo․

${ }^{173}$ Ibídem. Sesión del 17-XI-1556. Fols. 200ro-200vo.

${ }^{174}$ Ibídem. Sesión del 30-XII-1556. Fols. 203ro-204ro․

175 Ibídem. Sesión del 3-II-1557. Fol. 204oㅡ.

${ }^{176}$ Ibídem. Sesión del 10-IX-1557. Fol. 232ro․

${ }^{177}$ A.H.P. de Albacete. Secc. Municipios. Caja 4578. Libro 228. Cuentas de propios 1552-1564. Cuenta del 29-IX-1555 a 29-IX-1556.
} 
lario y gastos, consignados a Pedro Cebrián "o Alonso Herrandes, su padre, que se los enbíe"178.

En septiembre de 1560 el concejo albaceteño decide enviar un nuevo solicitador a Granada al constatar que los pleitos estaban desatendidos. El de los Alfaro ya estaba pronunciado "en vysta y en grado de rrebista por pecheros". Se acuerda traer a la villa la ejecutoria al respecto ${ }^{179}$, "que a munchos días que los Alfaros están sentençiados en rrevista por los sennores oydores de la Chançillería Rreal de Granada por pecheros. Y por no averse sacado la executoria, están en posesión de hidalgos ${ }^{\prime 180}$. Ocupaba ahora del cargo Esteban Pérez, que pedía dinero para pagar las costas y la propia ejecutoria. Se le enviaron cincuenta ducados, "y se benga luego"181. Un vecino le llevó "çiertas cartas y despachos para que se viniese"182.

Aunque el proceso ya se dio por concluso, años después, en 1612, y cuando el concejo ya no tenía memoria de ello, fue requerido por la Chancillería para continuarlo por demanda de la tal familia. El ayuntamiento expresaba no tener noticia de tan antiguo litigio. Se buscaron las escrituras en el archivo y, efectivamente, se comprobó que el pleito estaba concluso y los Alfaro declarados pecheros (Córcoles, 2017, p. 95).

A pesar de que, como ha señalado Moreno (1984, pp. 27-34), generalmente era el pretendiente a hidalgo el que iniciaba el pleito con el concejo, como consecuencia de ver su nombre incluido entre los pecheros y, por tanto obligado a pagar, en nuestro caso vemos que es el propio ayuntamiento quien a veces se adelantaba al respecto. En las sesiones de los días 2 y 3 de septiembre de 1560 se evidencia claramente esa práctica. En la primera de ellas los oficiales mandaron notificar a todas las personas que ostentasen esa condición, que presentasen los títulos correspondientes, "para ver a los que se les puede poner demandas" ${ }^{\prime 83}$. En la segunda se ordena al solicitador en Corte que ponga denuncia a todos los vecinos que se hacen pasar por hidalgos sin serlo, porque "ay munchas personas en esta villa que están en posesión de hidalgos, siendo pecheros e deçendientes de pecheros".

${ }^{178}$ Ibídem. Cuenta del 29-IX-1556 a 29-IX-1557.

179 A.H.P. de Albacete. Sec. Municipios. Caja 4507. Actas capitulares 1552-1562. Sesión del 2-IX-1560. Fol. 346rํ․

${ }^{180}$ Ibídem. Sesión del 3-IX-1560. Fol. 347ro .

${ }^{181}$ Ibídem. Sesión del 7-X-1560. Fol. 353vo․

${ }^{182}$ A.H.P. de Albacete. Caja 4578. Libro 228. Cuentas de propios 1552-1564. Cuenta del 29-IX-1560 a 29-IX-1561.

${ }^{183}$ A.H.P. de Albacete. Sec. Municipios. Caja 4507. Actas capitulares 1552-1562. Sesión del 2-IX-1560. Fol. 346rº 
[...] E se ponga demanda a las personas siguientes: los hijos de Juan Rramírez, Juan de Frías, Juan de Saavedra, los hijos de Graviel d’Espinosa, Pedro de Cantos, Graviel de Guzmán, los hijos de Antonio de Vera, los hijos de Alonso Hurtado, los hijos de Diego Hurtado, Gaspar de Cantos, Andrés de Cantos, los hijos de Martín de Cantos, los hijos de Benito Cantos"184.

Junto con otras familias, los Frías, Saavedra, Espinosa, Cantos, Vera y Hurtado, ya se querellaban por la hidalguía en años anteriores e incluso, alguno de ellos, después (Moreno, 1984, pp. 27-34).

A través de las cuentas de propios hemos podido sacar una estimación aproximada de los gastos del concejo de Albacete, motivados por los distintos litigios que mantuvo durante el período de nuestro estudio. No se contienen las liquidaciones, hechas al final de su gestión, a procuradores, solicitadores y letrados.

\section{GASTO APROXIMADO EN PLEITOS (1555-1561)}

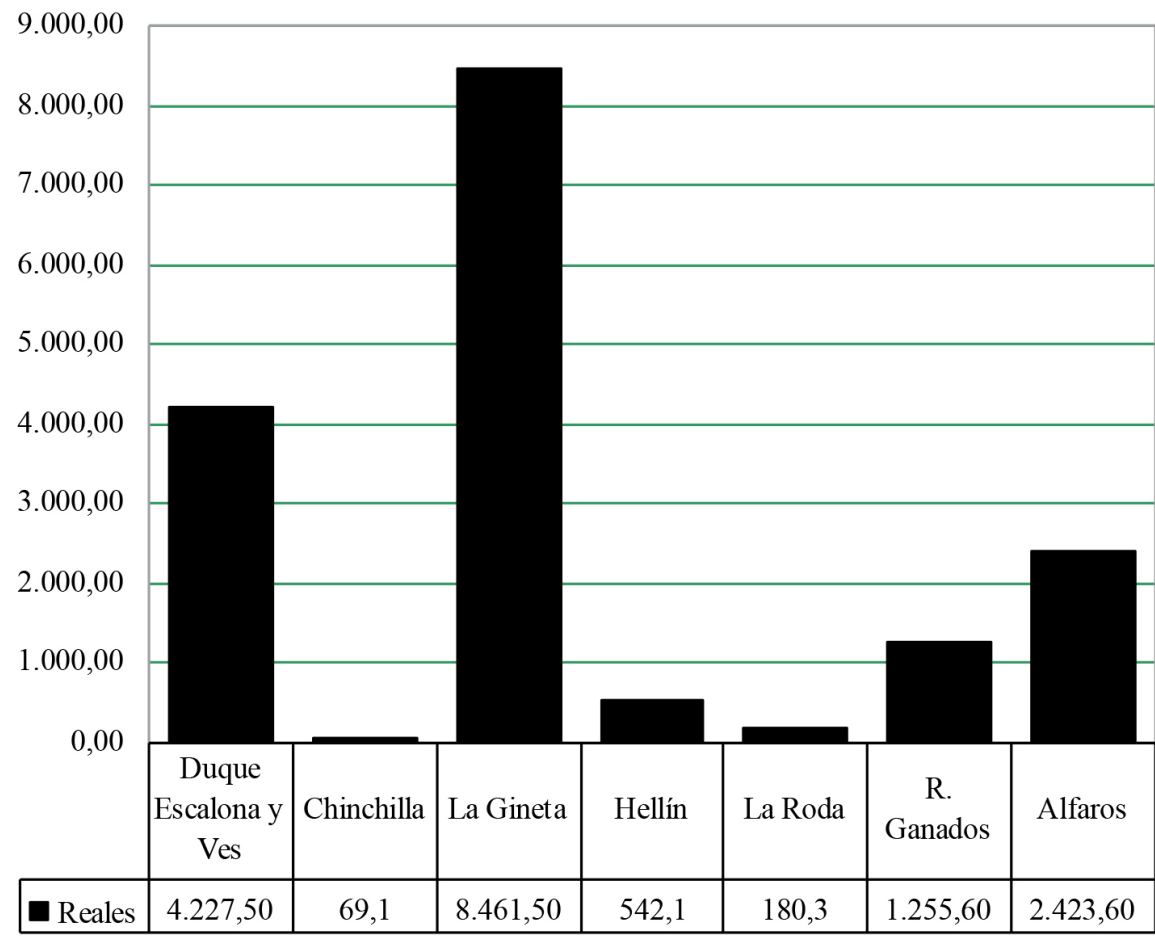

\footnotetext{
${ }^{184}$ Ibídem. Sesión del 3-IX-1560. Fol. 347roํ.
} 
En el gráfico de la página anterior puede observarse que los cuatro más destacados son aquellos cuyos procesos se llevaron a cabo en la Corte y en la Chancillería de Granada. Los otros tres se libraron dentro del Marquesado de Villena, bien en Chinchilla o en San Clemente, según fuese el alcalde mayor o el gobernador quien dictaminase.

Dentro de los de mayor cuantía, destaca el costo con La Gineta. Hay que tener en cuenta que esta causa comienza prácticamente en ese momento, pues la nueva villa se había independizado en 1553. Los mayores gastos (procuradores, solicitadores, testigos, escribanía, etc.) se suelen dar en los inicios, para poner todo en marcha. El resto de procesos que se gestionaban fuera del Marquesado, ya estaban comenzados en 1555.

La suma de gastos en pleitos fue de unos 17.160 reales. Si tenemos en cuenta que el concejo libró, por administrar la villa en ese tiempo, unos 64.345 reales $^{185}$, se habría empleado en querellas casi el $27 \%$ del total de los pagos.

\section{OTROS PLEITOS}

El horno con vivienda, situado junto a llamada Casa de Las Beatas $^{186}$, fue motivo de discordia en estos años. El 7 de diciembre de 1555, el emperador Carlos V, mediante carta ejecutoria, exige el cumplimiento de dos sentencias que fallan a favor del concejo de Albacete en el pleito que mantenía con la familia Villena sobre la propiedad de "vnas casas de horno de pan cozer que eran en el sitio de la dicha villa, linde de vna parte de casas de Las Beatas y, de la otra, casas de Bartolomé de Cannauate". Esa familia por un lado y el consistorio por otro, reclamaban la propiedad del inmueble y su explotación. El alcalde mayor del Marquesado daría la razón en un principio a los Villena, pero el concejo albaceteño apeló ante la Corte, que dictaría sentencia en su favor. Recurriría por ello la parte contraria y el emperador confirmaría definitivamente su veredicto anterior (Carrilero 2000, pp. 436-443).

En las cuentas de propios de 1554-1555 y 1555-1556 no hay constancia de que el concejo tomase renta alguna de ese horno, al no estar arrendado por la causa pendiente. Sí se reflejan algunos pagos que se hicieron con motivo de la misma. Así, se dieron al escribano Juan

${ }^{185}$ A.H.P. de Albacete. Secc. Municipios. Caja 4578. Libro 228. Cuentas de propios 1552-1564.

${ }^{186}$ Se trataba de un convento de monjas franciscanas formado en el primer tercio del siglo XVI. Anteriormente fue un beaterio, de ahí que se siguiese llamando de Las Beatas. Actualmente es el Centro Cultural de la Asunción, sede del Instituto de Estudios Albacetenses. 
Berruga seis reales por el traslado de la ejecutoria del horno concejil "que tenían los herederos de Françisco de Billena". Además, el mayordomo libró cuatro reales a un peón "que truxo vnas cartas de Granada sobre lo del horno"187.

En los cinco períodos siguientes, desde 1556-1557 hasta 15601561, el concejo cobró 6.500 maravedís de renta en cada uno de ellos, por el horno y casa "junto a Las Beatas"188. Por lo que el asunto ya estaba concluido en su favor.

En otro caso, el mayordomo Miguel Sánchez recibiría orden de tomar prestados, "del trigo e harina que conprastes el anno pasado para mantenimyento desta villa", hasta doce reales. Cantidad que debía entregar al procurador en Corte, Tristán Calvete, encargado de recibir traslado y responder a la demanda que puso la villa de Jumilla. El asunto versaba sobre el servicio que se le cobró a un vecino de ese lugar, "de çiertas varas de cordellate que vendió" en Albacete. Por ello también se libraron cuatro reales a un almanseño que llevó los despachos y otros cinco a un peón que llevó más documentación al tal procurador, "sobre que pidió vno de Jumilla ser franco" 189.

También, el aprovechamiento de términos entre las distintas villas del Marquesado de Villena, que previamente lo hubieren concertado, legitimaba a cualquiera de ellas a demandar a quienes se apoderasen en exclusiva de los bienes de uso común. El 2 abril de 1560, se recibió comunicación de un regidor de Yecla, llamado Pedro Vicente, de que los abrevaderos de Bonete estaban ocupados. Albacete, con disposición a colaborar en el asunto, acordó dar poder a Yecla para que actuase en consecuencia ${ }^{190}$. Dos días después se recibió una carta de esa población confirmando lo antedicho. En ella se explicaba que Miguel de Reina, vecino y regidor de Chinchilla, había tomado esos bebederos. Aunque el consistorio albaceteño insistiría en dar licencia al concejo yeclano,

para que tome el pleito en sí e lo defienda, porquesta villa (de Albacete) tienen otros muchos pleitos que seguir. Acordaron que se le escriba a la dicha villa de Iecla, que tomen a su cargo la soleçitud del dicho pleito y que esta villa contribuirá como es costunbre en el gasto. Y lo demás lo cometen al sennor Alonso Benítez, rregi-

\footnotetext{
${ }^{187}$ A.H.P. de Albacete. Secc. Municipios. Caja 4578. Libro 228. Cuentas de propios 1552-1564. Cuenta del 29-IX-1555 a 29-IX-1556.

${ }^{188}$ Ibídem. Caja 4578. Libro 228. Cuentas de propios 1552-1564.

189 A.H.P. de Albacete. Secc. Municipios. Caja 4578. Libro 228. Cuenta del 29-IX1557 a $29-$ IX-1558.

${ }^{190}$ A.H.P. de Albacete. Sec. Municipios. Caja 4507. Actas capitulares 1552-1562. Sesión del 2-IV-1560. Fol. 326ro․
} 
dor, para que conplirá lo que tratare y conçertare con la dicha villa de Yecla ${ }^{191}$.

\section{CONCLUSIÓN}

Los pleitos abarcaron la mayor preocupación de los regidores de la villa de Albacete en el tiempo que tratamos. La controversia por los diversos asuntos fue motivo de inquietud a mediados del siglo XVI, aunque no desvelos exclusivos de ese tiempo. El concejo se vio involucrado en una serie de enfrentamientos que le ocasionaron molestias y gastos.

Para llevar a cabo este cometido, se hubo de emplear a procuradores, solicitadores y letrados en la Chancillería de Granada y la Corte. Peones y correos salían de Albacete en dirección a esos lugares con mensajes y órdenes determinadas del ayuntamiento respecto a las cuestiones pendientes de resolución. Unas veces cumpliendo y consiguiendo su cometido, otras de vuelta a la villa manchega sin haber resuelto nada; bien por la lentitud de los procesos, la falta de credenciales, e incluso la negativa a regresar a la población de los encargados. A veces incluso pidiéndoles que dejasen el asunto en estado inconcluso, aún cuando el gasto fuese inútil. La impresión general es que nada terminaba de resolverse, las causas quedaban en estado de revista y el tiempo iba pasando sin que hubiese una claridad total en la resolución de los procesos. Muchas fueron las causas que se representaron, aunque nosotros hemos tratado las que más preocupaban a los oficiales que regían el pueblo.

Las villas de Alcalá del Río (Alcalá del Júcar) y Jorquera habían quedado para el Marqués de Villena, tras la concordia de 1480 por la guerra civil que le enfrentó a los Reyes Católicos. A pesar de la costumbre inmemorial que permitía a Albacete pacer con sus ganados, mediante el pago de ciertos impuestos, en las tierras del Marqués, sus descendientes no toleraron esa intromisión y los enfrentamientos desembocaron en pleito. Tampoco las resoluciones que se dieran las acató la villa de Jorquera de buenas a primeras. Incluso hubo que recurrir a receptores reales para que ese lugar acatase las ejecutorias.

Con Chinchilla los enfrentamientos venían sucediéndose desde que Albacete se segregó como villa independiente en 1375. El aprovechamiento de terrenos comunes y los límites de sus términos fueron la causa latente del conflicto que no terminaría nunca de resolverse. La otrora metrópoli no admitió nunca en la práctica el desgajamiento de una parte de su territorio como libre e independiente de su influencia. Actitud que a su vez adoptó la población albaceteña cuando fue la

${ }^{191}$ Ibídem. Sesión del 4-IV-1560. Fols. 327ro-327ํo. 
Gineta la que se apartó, por privilegio real, de su tutela. Aunque en este caso era la nueva villa vecina la que hostigaba negándose a pagar, en los plazos previstos, los impuestos reales que aún mantenían en común. E incluso invadían la jurisdicción colindante con altercados y enfrentamientos físicos.

También el conflicto sobre el registro de ganados con los jueces de sacas y puertos secos, no llegó a resolverse del todo, dada la impunidad que ostentaban esos agentes. Lo cual llevó a la anecdótica actuación del pueblo albaceteño respecto a su entrada y salida de la zona de las doce leguas del límite del Reino de Valencia, con tal de luchar por conseguir no hacer efectivo ese asiento.

Igualmente el conflicto con vecinos que pretendían la hidalguía, les llevó a enfrentarse a nivel supramunicipal, dadas las ventajas, sobre todo de tipo económico (además del social) que permitía esta condición. A lo que el concejo se resistía ante la posibilidad de una pérdida de ingresos tributaria.

La consecuencia y conclusión principal de todos estos conflictos señalados, y algunos más, fue que, debido a su larga duración, desembocaron en sobrecostes en las arcas municipales, llevaron al concejo a un débil estado de subsistencia económica, provocando la toma del dinero de otras partidas, préstamos de particulares y la venta de trigo para sufragar el alto gasto municipal que ocasionaban. 


\section{REFERENCIAS BIBLIOGRÁFICAS}

CARRILERO MARTÍNEZ, R. (1983). Libro de los privilegios de la villa de Albacete (1533). Estudio paleográfico y diplomático. Albacete: Instituto de Estudios Albacetenses.

CARRILERO MARTÍNEZ, R. (1987). Aportación documental al estudio de la historia de una villa del Marquesado de Villena: La Gineta (Albacete). Congreso de Historia del Señorío de Villena (pp. 85-94). Albacete: Instituto de Estudios Albacetenses.

CARRILERO MARTÍNEZ, R. (2000). Carlos V y Albacete. Albacete: Instituto de Estudios Albacetenses.

CARRILERO MARTÍNEZ, R. (2002). Colección documental albacetense de la reina doña Juana (1505-1519). Albacete: Instituto de Estudios Albacetenses.

CARRILERO MARTÍNEZ, R. (2004). Los Reyes Católicos en la documentación albacetense (1476-1504). Albacete: Instituto de Estudios Albacetenses.

CARRILERO MARTÍNEZ, R., GARCÍA MORATALLA, P.J., CIFO GONZÁLEZ, M., VALDELVIRA GONZÁLEZ, G. (2014). Pueblos de la provincia de Albacete en las Relaciones Topográficas de Felipe II. (Estudio documental, filológico e histórico). Albacete: Instituto de Estudios Albacetenses.

CÓRCOLES JIMÉNEZ, Mํㅗ P. (2002). Los regidores de la villa de Albacete durante la segunda mitad del siglo XVI. II Congreso de Historia de Albacete. Vol. III. Historia Moderna (pp. 29-45). Albacete: Instituto de Estudios Albacetenses.

CÓRCOLES JIMÉNEZ, Ma P. (2008). La villa de Albacete en la primera mitad del siglo XVII: Estructura y funcionamiento de la administración municipal. Albacete: Instituto de Estudios Albacetenses.

CÓRCOLES JIMÉNEZ, Mà.P. (2017). "Las personas de mayor lustre que en esta villa hay". Hidalgos en la villa de Albacete (1550-1650): Participación en la vida municipal. Albacete: Instituto de Estudios Albacetenses.

GARCÍA MORATALLA, P.J. (2020). El pueblo albaceteño en tiempos de Felipe II (1556-1598). En A. Pretel (Coord.), Historia de Albacete. Del siglo X al XX (pp.115-138). Albacete, Ed. Altabán.

GONZÁLEZ ARCE, J.D. (2002). La fiscalidad del Señorío de Villena en la Baja Edad Media. Albacete: Instituto de Estudios Albacetenses.

GONZÁLEZ ARCE, J.D. (2016). Arrendamiento de rentas reales y negocio fiscal en el Señorío de Villena a finales de la Edad Media. Albasit, 61, 5-53. 
MORENO TRUJILLO, Maㅡ A.: (1984). Noticia de los pleitos de hidalguía de Albacete en la primera mitad del siglo XVI en la Real Chancillería de Granada. Congreso de Historia de Albacete. Vol. III. Edad Moderna (pp. 27-34). Albacete: Instituto de Estudios Albacetenses.

PRETEL MARIN, A. (1986). El nacimiento de Albacete. Albacete, Cultural Albacete, 3.

PRETEL MARÍN, A. (2010). La villa de Albacete en la Baja Edad Media. Albacete: Instituto de Estudios Albacetenses.

PRETEL MARÍN, A. (2020). Albacete del siglo X al XV. En A. Pretel (Coord.), Historia de Albacete. Del siglo X al XX (pp. 21-84). Albacete, Ed. Altabán. 
